\title{
GENEL HUKUKI KORUMA ÇERÇEVESINDE BILIŞIM SUÇLARI
}

\author{
Prof. Dr. Yäksel ERSOY*
}

\section{I - GIRIŞ}

\section{Terim}

\section{1 Genel olarak}

Bilgisayarın ortaya çıkışı, gelişmesi ve kullanımının yaygınlaşmasıyla, genel olarak toplum hayaunda ve ózellikle bilimin çeşitli dallarında adeta yeni bir çą̧ açılmışur. Gittikçe daha çok gelişen bilgisayar sistemleri, hazırlanan ozzel programlar aracılığıla, depolanan bilgileri büyük bir hızla işleme tabi tutmakta ve sonuçlan, gerekirse yazılı olarak (basılı çıku), grafik yahut görüntü şeklinde üretmektedir.

Bilgisayarlann hukuk alanında kullanımı da çeşitli yơnleriyle hukuk çalışmalarını ve araşurmalanıı kolaylaşunılmış, bilgilerin daha düzenli toplanması ve daha hızlı bir şekilde bunlardan yararlanılması olanağını sağlamışur.

Toplum hayaunın ve bilimin hemen her alanında bilgisayarlann ve bilgisayar esasına dayalı bilişim araçlarının kullanımı ile birlikte bir "bilgisayar dili" ortaya çıkmış ve her dilde bilgisayar sőzlükleri yayınlanmıştır. Ülkemizde yayınlanan bu tür bazı sözlüklere aşağıda terim konusunu ele alırken göndermede bulunacağz.

Ancak, burada "bilgisayar dili" demek suretiyle anlatmaya çalışuğıııı, genel anlamda ve bilgisayar esasına dayalı sistemler, donanımlar, yazılımlar ve işlemlerle ilgili özel sőzcüklerin veya deyimlerin tümünü kapsayan dil kavramını, bilgisayar programlarında kullanılan "dil" kavramı ile kanş̧ırmamak gerekir. Bu anlamda dil, "Belli bir işlemi tasarlamak üzere kullanılan, kendine ozgü sőzdizim kurallan ve ozelliği olan ‘

*A.U. Siyasal Bilgiler Fakultesi Ogrretim Uyesi 
kurallar" bütününü ifade etmekttedir. ${ }^{1}$ Başka bir tanım bu anlamda "dil" $i$, "Bilgi iletide kullanılan kurallar ve gősterimler dizisi" olarak belirlemektedir. ${ }^{2}$

Dolayısıyla, burada sóz konusu olan programlama dilleridir. "Programlama dili", bilgisayar programlan oluşturınak için tanımlanmış kurallar ve gosterimler dizisinden oluşmaktadır. Bu anlamda .alen uygulanmakta olan birką̧ programlama dili bulunmaktadır. Programlama dilleri çeşitli şekillerde tasnif edilmektedirler. Bunlar, alt düzey dilleri (low level langua yes), üst düzey dilleri (high level languages), etkileşimli diller (interactive languages), ALGOL grubu diller, ozel uygulama dilleri gibi gruplara ayrilmaktadir. ${ }^{3}$

Bugünkü aşamada terim konusunun, ozellikle hukuk alanında, yeterli netlik ve açıklıła kavuşturulduğu sőyler.emez. Bu bakımından, oncelikle terim konusunu genel olarak ele alıp, daha sonra hukuk alanındaki durumu değerlendirmekte yarar vardır.

Gerek bilgisayar, gerek bilgisayara dayalı diğer sistemlerin, araç ve gereçlerin ortaya çıkuğı ve en yeni gelişmo:lerin ve kavramların kullanıldığı yer olan ABD'nde terim konusunda yapılan degerlendiımeler, diğer ülkelerde onerilen ve kullanılan terimler bakımından da etkili olmaktadır. Ülkemizde de genel olarak bu alanda kullanılan ve daha sonra hukuk alanına da giren terimler ABD'nde kullanulanlann sevirisi niteligindedir.

"Bilgisayar"4 kısa bir tanımla bilgi depolayıp işleme tabi tutan ve sonucunu gossteren bir araçur. Ancak bütün unsurlarını içerecek bir tanım yapmak isteyenler, sonuçta aynı kavramı tanımlarıakla beraber, birbirinden az veya çok farklı tanımlar vermektedirler.

Bilgisayarın esas teşkil ‘utiği sistemler ${ }^{5}$ ve buna bağlı diğer geliş̧meler, hemen hemen bütün bilim alanlanna katkıda bulundukları gibi, kendileri de yepyeni bir araştırma alanını oluşturmuşliı ve yeni bir hukuk alanının ortaya çıkmasına yol açmışlardır.

1Ozlem Meltem Kurtaran-Farul: Çubukçu, Ansiklopedik Bilgi Işlem Terimleri Sözlügŭu, Tümen Kitabevi, Istanbul, 1971 , s. 60.

2Mayda Gürsel-thsan Gürsel, Buyưk Bilgisayar Terimleri Sözlügü, Doruk Yayınlan, Ankara, 1991, s. 185.

3 Alt düzey diller, makine bağımlı ve programcıya geniş olanak tanıyan dillerdir. Ust düzey diller, BASIC, COBOL, PASCAL, C gibi kullanımı genel amaçlı ve çoklukla belli bir alana özu olan dillerdir. Ėtkileşimli diller, kullanıcı ile diyalog sağlayan eł̧itim ve bilimsel amaçlı dillerdir. Ozel alanlar için geliştirilen diller, LISP. SIMULA, COGO gibi matematiksel konular ve bentcri alanlar için geliştirilmişlerdir. Bu konuda ayrıntıh bilgi için Kurtaran-Çubukçu, a.g.e. içerisinde çeşitli kavtamlarla ilgili olarak yapılan açıklamalara bakınız.

${ }^{4}$ Kurtaran-Çubukçu , a.g.e. s. 32: "Çok sayıda aritmetiksel ve mantıksal işlemleri bir işletmenin katkısına gereksinim duymadan, önceden yüklenmiß̧ program temelinde otomatik olarak yưrüten makinedir." Gürsel-Gürsel, a.g.e. s. 63: "Problem çכ̋zebilen veya veri alıp manipüle edebilen, veri üzerinde istenen işlemleri (Matematiksel ya da mantıksal) yapabilen vẹ bu işlemlerin sonuçlarını gösterebilen alet."

5 Kurtaran-Çubukçu, a.g.e., s. 35: "Bilgisayar sistemi: Bilgi işlemde bir birim olarak kullanılan bilgisayar donanımı ve yazılımı". 
"Bilişim" (informatics) terimi ise, bilginin elektronik olarak işlenip, yüksek hızlı veri, ses ve görüntü taşıyan iletişim hatlan aracılığıyla aktanılmasını ifade eder. ${ }^{6}$ Bilişim araçlan terimi, bilgisayarlarla birlikte, bilgisayar esasına dayanmakla beraber daha geniş kullanımı olan diǧer araçlan da kapsar. Türk Ceza Kanununa "Bilişim Suçları" bolümünủ eklemek üzere yapılan hazırlık çalışmalannda, Adalet Bakanlığının hazırladığı gerekçede "Bilişim alanı" kavramı "Bilgileri toplayıp depo eutikten sonra bunlan otomatik olarak işleme tabi tutma sistemlerinden oluşan alan" olarak tanımlanmışur. ${ }^{7}$

\section{1 . 2 Hukuk alanında}

Terimlerin isabetli seçim ve kullanımı bakımından, oncelikle inceleme alanının doğru olarak belirlenmesi gerekmektedir.

"Bilişim (informatics) suçu" denince bilgisayan (computer) da kapsayan ancak daha geniş olan bilişim araçlarına karşı veya bilişim araçlan ile işlenen suçlar anlaşılmak gerekir. ${ }^{8}$ Ancak, bilişim araçlannın en yaygın olanının bilgisayarlar olması ya da, daha doğru bir deyişle, diłger bilişim araçlarının da bilgisayar esasına dayanması 'nedeniyle, genel olarak "bilgisayar sụçu" (computer crime) kavramı da kullanılmaktadır.

Bilgisayarlann ve bilgisayar esasını kullanan diğer sistemlerin orkaya çıkışı ve gelişmesi ve bu durumun yol açıŏ̀ sorunlar bugün bazı çalışmalarda "bilgisayar hukuku" (computer law) genel başlı̆̆ı alında yer alan kurallar bütününü ortaya çıkarmışur. Bu alanda da esas itibariyle genel hukuk kurallarnnın uygulanacag $y_{1}$ ve sadece koninun mahiyetine uygun ozzel birtakım düzenlemeler yapılacał̧ı göz önünde tutulunca, konunun boylesine bağımsız ve yeni bir hukuk dalını ortaya çıkanp çıkarmadığı tartışılabilir.

Bilgisayarnn ya da daha geniş anlamda bilişim araçlarının gelişimi, değişik hukuk alanlannda yeni ozel hükümlerin ongörülmesi ihtiyacını ortaya çıkarmışur. Sadece iç (ulusal) hukukların şeşitli dallarında değil, uluslararası ozel ve ceza hukuku alanlarında da yeni düzenlemeler yapılması gerekmektedir. Değişik hukuk alanlannı ilgilendiren bu hükümlerin, ozzellikle konunun teknik yönü hakkında da bilgi sahibi olan hukukçular taraf undan, bir başlik altunda incelenmesinde yarar vardir.

"Bilgisayar hukuku" denince, enformasyon teknolojisini düzenleyen hukuk dalı olarak anlaşılmakta: enformasyon teknolojisinin esas itibariyle bilgisayarlan ifade euiği, ancak potansiyel olarak telekomünikasyon ve yayın (broadcasting) gibi bilgilerin (information) aktanldığı araçlan da kapsadığı belirtilmektedir. ${ }^{9}$

Bizim hukukumuzda, Ceza Kanununa eklenen "Bilişim Suçları" bơlümü, bir bakıma bilgisayar terimi yerine daha geniş kapsamlı kabul edilen bilişim teriminin tercih edildiğini göstermektedir. Bu terimin suçlar bakımından kabulü, daha genel

${ }^{6}$ Kurtaran-Çubukçu, a.g.e., s. 35; Gürsel-Güsel, a.g.e., s. 169.170.

${ }^{7}$ Faruk Erek, "Bilgisayar Suçları ve Türk Ceza Kanunu". Yargıtay Dergisi, cilt 17. Ekim 1991. sayı: 4 sayfa: $436-444$.

${ }^{8}$ Kavram konusunda ayrıntılı bilgi için bkz.: Oykü Didem Aydın, "Bilişim Suçları". Bilişim '93 Bildiriler. Türkiye Bilişim Demeģi Bilişim '93 Etkinlikleri, 28 Eylül - 1 Ekim 1993, INTERPRO Yayıncilk, Istanbul, s. 72-81.

${ }^{9}$ Computer Law, edited by Chris Reed, Blackstone Press Limited, Londra, 1990, s. 1. 
deģerlendirmelerde de "bilişim hukuku" (law of informatics - information law) teriminin kabulüne yol açabilecektir. Bilişim hukuku terimine, bu terim çok geniş kapsamlı olduğu, sỏzleşme ve idare hukukunun bir kısım konularını da kapsayacağı gerekçesiyle karşı çıkılmakta; "bilgisayar hukuku" teriminin birleştirici tarafının bilişimin teknolojik yơnlerini yani bilgi işlemi (information processing) düzenleyen kuralları incelemesi olduğu belirtilmektedir. ${ }^{10}$

ABD'nde başlayan ve gerek orada gerek diğer ülkelerde sistemlerdeki geliş̧melere paralel olarak daha aynntılı değerlendimelere yönelen terim çabalanının bugün yerine oturmuş oldugưunu ve net bir terminolojiye ulaşuğını sơlemek mümkün değildir. ${ }^{11}$ Alanı net bir şekilde belirlenmek kaydıyla bir ya da diğer deyimin kullanılmasının çok onemli sonuç doğurmayacağı düşünülebilir.

Biz burada, kanunun kullanıldığı "bilişim" terimini esas almakla beraber, "bilgisayar" terimini de, genellikle geniş anlamda alarak her iki terimi eşanlamlı şekilde kullanacağı.

\section{Bilişim alanında gelişmeler ve hukukî düzenleme}

Bilgisayarlar ilk olarak 1950'li yılların başında ABD'nde üretilmeye başlanmışu. Kapasitelerine göre çok ağır ve hacimli olan bu âletler aynı zamanda da çok pahalıya mal olmaktayd. ${ }^{12}$ Ancak nisbeten kısa bir zamanda büyük bir gelişme saglanmış ve ucuza kullanıma sunulan çok büyük kapasiteli, çok hızlı ve eskiye oranla inanılmaz ucuzlukta bilgisayarlar ve diģer bilişim araçları piyasaya sürülmüş ve yavaş yavaş dünya çapında uygulama alanı bulmuştur. ${ }^{13}$ Gelişmenin gittikçe artan bir hızla devam ettigyi, yeni kullanım alanlan ${ }^{14}$ için yeni araçların icat edilip piyasaya sunulduğu bir gerçektir. Bu gelişmelerin yakın ve uzak gelecekte saglayacakları imkânlan şimdiden bilebilmek de mümkün değildir.

$10_{\text {Reed, a.g.e. s. } 2 .}$

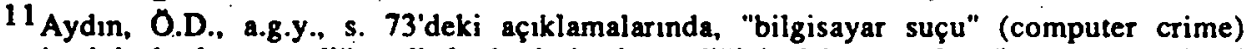
isminin başlangıçta diğer ulkelerde de benimsendighini; daha sonralan "computer-assisted crime" gibi bir kavram ortaya atıldığını; bilgisayara karşı işlenen suçlar için "crimes against computer" teriminin kullanıldığını; Italya'da "elektronik suçları". (reati elettronici) deyiminin yanında bilgisayar suçlarıyla ilgili olarak "enformatik cürmü" (dolo informatico) deyimine yer verildigini ifade etmektedir.

12 Emin D. Aydın, a.g.e., s. 8: "ABD'de 1952 yılında her biri 1 milyon dolar değerinde (paranin bugünkü değeriyle yaklaşik 12 milyon dolar) birką̧ bilgisayar bulunmaktaydı. (1946'da dünyanın ilk sayısal bilgisayarı 'ENIAC' 30 ton ağırlığında ve $18000^{\prime}$ vakum tüpünden oluşuyordu). Herbir bilgisayar için $20 \times 10 \mathrm{~m}$.lik bir alana gerek duyuluyor"du.

${ }^{13}$ Ozellikle yakın geçmişte "kişisel bilgisayar"ların (personal computer) gelişmesi ve bunlann "lap-top" veya "book-size" tiplerinin ortaya çıkması bilgisayar kullananlann sayısında ve bilgisayarın kullanıldığı alanlarda büyük artışa yol açmıştır.

${ }^{14}$ Aydın E.D. a.g.e., s. 10 vd: bilişim teknolojisinin yeni uygulamalanı olarak, çeşitli mal ve hizmetlerin ev terminalleri aracılığyla satın alınması, pazarlama sistem ve stratejileri, elektronik ödeme işlemleri, güvenlik ve savunma sistemleri, videoteks, uydu televizyon, elektronik posta, hava tahmini, bilgi bankalar, otomobil mikrobilgisayarlanı gibi alanlardaki kullanımları ömek vermektedir. 
Bu ortamda, bugünkü gelişmelere uygun hukukî düzenlemelerin yapılması bile güçlük gösterirken, bu düzenlemelerin, ne kadar geniş ve kapsamlı düşünülürse düşünülsün, ileride yetersiz kalmalan da kaçımılmaz olacaktur. Bu bakımdan, teknolojinin bu kadar süratle geliştigi ve bireysel ve toplumsal ilişkileri derinden etkilediği bu konularda, hukuk alanında da buna ayak uyduracak bir tempoda değeriendirme yapılması gerekir.

Teknolojiyi üreten ve deģişik düzeylerde kullanan ülkeler arasında düzenleme bakımından farklar ortaya çıkması kaçınılmaz olacaktur. Kendi üretim ve kullanım düzeyine bakmadan, daha ileri düzeyde sistemlerin mevzuatuna göre değerlendirmeler yapılması halinde, ongorïlecek hukuk kurallannın yeterli hayatiyete sahip olamayacaklan da søylenebilir. Bizim mevzuatımızda oncelikle ozel hukuk bakımından birtakım değerlendirmelerin yapılması, birtakım ihlâlleri bzel hukuk yapurımları ile ve daha olmazsa idare hukuku yaptınmlan ile onlemenin yollarının aranması ve ancak ondan sonra ceza yaptırımını gerektiren hallerin ortaya çıkarılması gerektiren, doğrudan doğruya ceza mevzuaunda bir kategori suç óngơrülmesi, uygulaması olmayan veya çok az olan bir suç kategorisine yol açmışur.

\section{II- GENEL OLARAK KORUMA}

\section{Koruma ihtiyacının ortaya çıkışı}

Bireylerarası ya da birey-toplum ilişkilerini ilgilendiren her yeni gelişmenin bu ilişkileri kurala bağlama gereğini ortaya çıkardığı ve sonuçıa düzenleyici ve koruyucu kuralların oluşturulduğu bilinen bir gerçektir. Bu ilişkilerde kuralları ihlâl eden davranışların ortaya çıkması da hayaun kaçınılmaz gerçeģidir. ${ }^{15}$

Bilişim araçlarının kullanılmaya başlanmașı ile birlikte bu araçlara karşı veya bu araçlar vasıtasıyla işlenen ve başkalarının ya da toplumun menfaaterini ịhlâl eden fiilerin hukukî bakımdan değerlendirilmesi ve bunlara karşı korunması ihtiyacı da ortaya çıkmışur.

Bilgisayarla ilgili "haksız davranıs"ların ne şekilde yasal düzenlemeye kavuşturulacağının belirlenmesi, bu konunun mahiyetinin ve boyutlarının iyi anlaşılmasına bağlıdır. Yabancı úlkelerde yıllardır bu konuda yapılan araşurmalara rağmen düzenleme güçlükleri çekilmektedir. Ülkemizde bu konunun boyutlan üzerinde yeterli araşırmaların yapıldığı ve haksız davranışların mahiyetleri hakkında net bir fikre ulaşıldığı söylenemez.

Bilgisayarlar ilgili "haksız davranıs" derken çok geniş.bir kavram kullandığımızın bilincindeyiz. Çünkü bununla. bilgisayar kullanımı ile birlikte ortaya çıkan ve herhangi bir yaptınm uygulayarak önlenmesi gereken her türlü haksız davranışı kastetmek

${ }^{15}$ Aydın E.D., a.g.e., s. 12: "Bilişim alanındaki gelişmeler, toplumu ve bireyi birçok yönden etkilemektedir. Her teknoloji devriminde olduğu gibi, gelişmenin getirdiği yararların yanısıra birtakım olumsuz etkiler de söz konusu olmaktadır. Omeł̧in, kimya bilimi çeşitli alanlarda kaydedilen gelişmeye büyük katkılarda bulunmuş ancak bu arada insan ve çevre için zararlı ürünler ortaya çıkmıştır. Motorlu araçlar yaşam tarzımızı, iş yaşamımızı, bo zamanımızı değerlendirme şeklimizi değiştirmiş, ancak bu arada trafik kazalarını, alkollü araç kullanma sorunlarını ve çevre kirliliģini beraberinde getirmiştir". 
istiyoruz. Yapılacak değerlendirmelere göre, bu haksız davranışlann, değişik hukuk yapturımlan öngörulerek, onlenmesine çalışlacak ve, buna rağmen onlenemezlerse sonuçlarının giderilmesi gerekecektir.

Özellikle bilgisayar programlannın ve bunlar üzerindeki hakların esas itibariyle hukukî ve bu arada cezaî korunmasının sağlanması bakımından mevcut hükümlerin uygulanabilirliģi üzerinde durulmaktadır. Amerika ve Avrupa'da hakim olan yaklaşıma uygun olarak ülkemizde de bilgisayar konusunun sınaî ve teknik değerleri korumayı amaçlayan Markalar Kanunun ve thtira Beratı Kanununu ilgilendirmediği kabul edilmektedir. Bilgisayar programlan tizerindeki hakların, fikni haklar çerçevesinde degererlendirilmesi gerektił̧i görüşünden hareketle 5846 sayılı Fikir ve Sanat Eserleri Kanunu (FSEK) veya 3257 sayılı Sinema, Video ve Müzik Eserleri Kanunu (SVMEK) hükümleriyle ơngơrülen hukukî ve cezaî korumadan yararlanıp yararlınamayacaklanı doktrinde tartışılmaktadır. Bilgisayar programlarının bu kanunlardaki tanımlar çerçevesinde "eser" sayılması suretiyle, eser sahibine tanına maddi (malî) ve manevî haklardan bilgisayar programcısı gerçek ve tüzel kişilerin de yararlanabilmesi gerektigi savunulmaktadrr. ${ }^{16}$

Bu meyanda bilgisayar programlannın FSEK'nun 2. maddesinde öngörülen "dil ile ifade olunan eserler" kavramına gireceğ ${ }^{17}$ veya aynı kanunun 84 . maddesinde düzenlenen "işaret" kavramı içerisinde kabul edilebileceğ ${ }^{18}{ }^{18}$ değerlendirmeleri yapılmıştır. Konuya netlik kazandınıması amacıyla, FSEK'nunda bir değişiklik tasarısı hazırlanmış ve "Bilgisayar Alanııın Korunması" başı̆ı̆ı alında dơst fukralık bir maddeye yer verilmiştir.

Kanunun gerekçesinde düzenleınenin amacı ve içeriği şoyle ifade edilmiştir: "Kanunun genel sistematiģini bozmadan, çeşidli hükümler kısmına üç madde biçiminde yeniliklerin eklenmesinde, üçüncü olarak da bilgisayar alanının konulması düşünülmüştür. Giderek gelişen bilgisayar alanının gereksinmelerini karşılamak ve ortaya çıkan hukukî sorunları gidermek üzere, Av̛upa Konseyi'nin hazırlamı̧ olduğu genel düzenleme doğrultusunda ve uluslararası mevzuat incelenerek yeni 82'nci madde hazurlanmıştır. Ülkemizde yeni gelişmekte olan bilgisayar sektörünün düşünceleri de alınarak hazırlanan bu madde genel anlamda bilgisayar sektorünün gereksinmelerini karşılayacak biçimde hazırlanmışur". 19

'Madde metni ise şరyledir: "Bilgisayar eseri, her biçim alundaki tüm programlanı ve bir sonraki aşamada program sonucu doğurması koşulu ile tasarım hazırlıklannı kapsar. Bir bilgisayar programı, eser sahibinin kendi düşüncesinin yaratımı anlamında özgän bir yapıya sahipse, eser sayılır. Aynca, bilgisayar programlarının ifadeleri de eser olarak kabul edilir. Ara yüzz̈ne temel oluşturan düşünce ve ilkeleri de içine almak üzere, bir bilgisayar programının herhangi bir elemanına temel oluşturan düşünce ve ilkeler ise bilgisayar programı sayılmazlar. Bilgisayar eserinin tüm haklan eserin sahibine aittir. Hak sahibinin yazılı iżni olmadıkça, bilgisayar programının herhangi bir yol veya

16 Emrehan Halıcı - Uğur Halıcı - Işık Aybay, "Yazılımda kopyanın yasal yollarla ónlenmesi", Bilişim' 93 Bildiriler. Türkiye Bilişim Demeği, 28 Eylül - 1 Ekim 1993. Istanbul, s. 70. Aydın, a.g.y. s. 79.

17 Aydin E.D., a.g.y., s. 120.

18 Aydin O.D., a.g.y., s. 79.

${ }^{19}$ Halıc1 - Halıc1 - Aybay, a.g.y., s. 70. 
biçimde tümünün ya da bir parçasının çợalulması, depolanması, kiralanması ve yayımına kadar tüm fiiler eser sahibinin yazılı iznine bağlıdır. Eserin ilk satışından sonraki durum eser sahibi ile yapılacak sózleșme ile belirlénir.- Bir istihdam koșuluna bał̧lantılı olarak yürüttülen bilgisayar programının eser sahipliģi hakkı aksi kararlaşunılmadıkça işverenindir. Eser sahipliği ile ilgili dił̆er konular, bu kanunun genel hükümlerine göre düzenlenir. - Bilgisayar programını kullanma hakkına sahip kişi, eser sahibinin izni olmadan kullanım için gerekli yedekleme nüshası üretebilir veya programa temel olan ilkeleri belirlemek için çalışmalar yapabilir."

Bu madde esas itibariyle Avrupa Birlił̧i ülkeleri için Konsey'in hazırlamış olduğu 14 Mayıs 1991 tarihli ve bilgisayar programlanının korunmasına ilişkin Talimat ilkelerini içermektedir. ${ }^{20}$

Ancak genel kanun çerçevesinde de olsa, bir maddeye sıkıştırılmak istenen düzenleme girişiminin eksiklikler içerdił̧i bilgisayar programı alanındaki uzmanlarca da ifade edilmektedir. 21

Kaldı ki bu şekliyle dahi tasarının kanunlaşması mümkün olmamıştır. Dolayısıyla, fikrî haklarla ilgili hükümlerin bilgisayar programı şeklindeki eserlere uygulanabilirliģi halen de tartışma konusudur.

Bunun sonucu olarak. bilgisayar programlarının bu kanunla fikri haklara tanınmıs olan korumadan yararlanması mümkün olmayacaktır. Kanunilik ilkesi gőz ơnünde bulundurulduğunda, ozzellikle, FSEK'nun cezaî korumaya yönelik hükümlerinin bilgisayar programlarına uygulanması kabul edilmez. Gerçi FSEK'nun ceza hükümlerinde ongorrülen korumanın bir kısmının Ceza Kanununun 525/a - 525/d maddeleri ile sağlandığı sరblenebilir; ancak bilgisayar programlarının genel kabul gören "eser" niteliģine dayalı korumanın oluşturulması ve Ceza Kanunu hükümleri ile ahenkli ve tutarlı bir hale getirilmesi ihtiyacı açıktır.

Daha ơnce de belirtildiģi üzere, koruma ihtiyacının ortaya çıması demek, bu fiillerin mutlaka suç sayılması demek değildir. Hukukî dȩ̧erlendirme sonucunda ihlâllerin onlenmesi için ozel hukuk ya da idare hukuku yapunmlan yeterli görïlebilir. "Bu alanda ceza yapunmlan uygulanmasının kapsamına ilişkin degerlendirme yapılırken, bilgisayar sahibinin ozel hukuktan kaynaklanan çareleri bulundugunun da akılda utlması onemlidir. Taruşma konusu olacak hallerin çợunda, fiiller bir memur tarafından işlenmiştir. Boyle bir halde disiplin kơ̧uşturması, belki hatta ișten çukarma, uygun bir cevap teşkil edebilir. Üçüncü bir şahsın fiilinin söz konusu olduğu halde ise, bilgisayar sahibi haksız fiil, sőzleşme veya güveni ihlâl kurallanndan kaynaklanan çarelere de sahip olabilir".22

20"Council Directive of 14 May 1991 on the Legal Protection of Computer Programs". Official Journal of the European Communities, 17. 5. 1991, n. 1 122/42-46. Bu talimat hükümleri üzerinde ayrıntılı inceleme için bkz.: \$afak Erel, "Fikri Hukukta Bilgisayar Programlanını Korunması", Siyasal Bilgiler Fakültesi Dergisi (Prof. Dr. Ilhan Oztrak'a Armagan), cilt:49, Ocak - Haziran 1994, n. 1-2, s. 141-164.

21 Halıc1-Halıc1-Aybay, a.g.y., s. 70.

22Ian Lloyd, "Computer Crime", Computer Law, s. 164. 
Ancak bu șekildeki korumanın yetersiz kaldığı hallerde ceza yapunımı ile korumaya başvurulabilecek, başka bir deyişle bu ihıâller su̧̧ sayılabilecektir.

Bu arada, bilişim alanında meydana çıkan birtakım fiillerin, mevcut ceza kanunlanında koruma konusu yapılmış bazı menfaatleri ihlâl etmesinin de mümkün olduğunu unutmamak gerekir. Bơyle bir ihlâl sơz konusu olduğunda, genel hükümlerin yeterli olup olmadı̈̆ı, dolayısıyla kısmen veya tamamen özel hükümler öngörmenin gerekip gerekmediği değerlendirmesi yapılacaktur.

\section{Bilişim ihıallerine yol açan ortam}

\section{1. Kendi kendine koruma ve yasal koruma}

Ilk sonunlar antaya çıkmaya başladığında, bilişim araçlanında kullanılan sistemlerin ve programlannın kendi kendilerini korumaya yeterli imkânlara sahip olduğu ve dolayısıyla ayn bir korumaya ihtiyaç duyulmayacał̧ı düşünülmüştü. ${ }^{23}$

Gerçekten, programların sauşında, program paketinin alıcı tarafından açılmasıyla kabul edildiģi varsayılan "lisans anlaşması" hükümleti ve aksine davranı̧ haline çeşitli yaturımlar getiren düzenlemeleriyle, alıcının ihlallerini onleyici bir ortam yaratılmaya çalışılmışur. Bu lisans anlaşmalan, bugün de gerek ozel hukuk gerek ceza hukuku bakmından korumanın temelini olușturmaktadrr.

Bunun yanında, ठzellikle programlanı kopyalanmasını onleyecek şifre sistemleri, kopyalama için ayn program düzenlenmesi gibi yơntemlerle en azından bir kısım ihlallerin ơnủ alınmaya çalışılmışur. Hattâ, bugün artuk bir ihlâl şekli olarak kendini gosteren virüs programlan da onceleri meşru (yasal) olmayan kopyalamaları onlemek amacıyla koruyucu olarak hazırlanmışı. ${ }^{24}$

Büttin bunlara rağmen konunun mahiyetinden kaynaklanan korumadaki büyük zorluklar karşısında kendi kendini koruma yanında yasal korumaların dahi yetersiz kaldığı goruulmektedir.

Orneğin "elektronik sinyallerle ifade edilen" paraya karşı alınacak tedbirlerin, nakit paraya karşı alınacak tedbirlerden temel olarak farklı oldugunda kuşku bulunmamakla beraber, elektronik sinyallerin klasik soygunlann yerini almasının, suç eylemlerine karşı alınacak koruma tedbirlerini onemli olç̧üde azaltı̈̆ından söz edilemez. ${ }^{25}$ Aslında bu durum tedbirleri azaltmamış, artırmışur. Klasik koruma yőntemlerinin devamı ihtiyacı

23 Aydin E. D., a.g.e., s. 14.

24 Adnan Mazmanoğlu, Bilgisayar Donanımı ve Bilgi Işlem Terimleri Sözlüłù, Istanbul, s. 32: "Yazılım haklarını korumak, yazılımın bir emek ürünü olduğu varsayımından geçer. Binbir emek ve göz nuru dökerek hazırladığınız bir programı sizden izin almadan bir kâr karşılıı̆ı kopya edip satan gózỉ açıklara kaŗ̧ı sizi kim korur? Yasalar. Yasalar yoksa siz de oturur sizin programınızı haksız kopyalayana karsı kullanıcı bilgisayarın belleğini rahatsız edici bir program yazarsınız, başka bir-kopyalanma durumunda o bilgisayarı da atıl duruma getirsin. Bir bulaşıcı mikrop gibi. Bu buna virüs diyoruz".

25 Aydın E. D., a.g.e., s. 55. 
yanında, yeni tür ihlâllere karşı yeni koruma yơntemlerinin digerlerine ek olarak alınması gerekmektedir.

"En hevesli bilgisayar taraftarı dahi bütün insan ozelliklerini bilgisayara atfetmekte güçlük çekeceği gibi, bu makine birçok fiziki parçalardan oluşmasına rał̆men, esas amacı, bilgi depolamak, işleme tabi tutmak ve yaymaktır ve böylece bugünkü 'bilişim toplumu'nun arkasinda yatan hareket gücünü sağlamaktadır. Bilgisayarın kơtüye kullanılmasının yaratığı sorunlara geleneksel ceza kavramlarının uygulanması bakımından en büyük güçlügüu, bilginin dokunulmaz, elle tutulmaz (intangible) yapısı oluşturmaktadır. ${ }^{26}$

\section{2. Bilişim ihlăllerinin işlenme nedenleri}

Her türlü hukuk kuralı ihlâlinde ve ozellikle suç teşkil eden hallerde asıl koruma ihlâlleri ơnleyici korumadır. Ihlâl olduktan sonra yapurnmla bunun topluma ya da kişiye vermiş olduğu zararın giderilmeye çalışılması, her türlü koruyucu ơnleme rağmen ihlâlleri tamamen ơnlemenin mümkün olmamasının kaçınılmaz soriucudur.

Bu bakımdan, asıl korumayı teşkil eden ónlemenin są̧lanabilmesi bakımından, genellikle ihlâllerin ve ozellikle suç teşkil eden ihlâllerin nedenlerinin araşunılması ve anlaşılması gerektiģinde kuşku yoktur.

Ancak bu araştırma, konusu ve yöntemi Ceza Hukukundan farklı olan Kriminolojinin alanına girmektedir. Yapılacak kriminolojik araştırmalar sonucunda bilişim suçlarının nedenleri saptanıp bunlarla mücadelede alınabilecek genel ve ozel onlemler belirlendiği ve uygulandığı takdirde, suç teşkil edebilecek davranışlar da azalacaktur. Bütün bu onlemlere rağmen devam etmesi muhtemel davranı̧lar ise Ceza Hukukunun konusunu teşkil etmeye devam edecektir.

Suç işleme nedenlerinin incelenmesi esas itibariyle Kriminolojinin konusunu teşkil etmekle beraber, Kriminolojik incelemelerden alınan sonuçlar, suçlarla ilgili kuralların düzenlenmesi ve cezanın bireyselleştirilmesi yőnünden de etkili olmaktadır. Bu bakamdan bu nedenlere kısaca değinilmesinde yarar görmekteyiz.

Herşeyden once, bilişim araçlanında ve kullanımındaki gelişimin, bir yönüyle, bazı suçların işlenmesini kolaylaşırdığı sơylenebilir. Çok sayıda bilginin, çok hızlı bir şekilde depolanması ve daha sonra yine çok hızlı bir şekilde işleme tabi tutulması, bu bilgilerin sürekli kontrolü imkânını azalımaktadır. Bu kontrol zorluğu ve bilgisayar kullanımında anonimlik suçluluğa elverişli bir ortamın oluşmasına yol ą̧makıadır. ${ }^{27}$

Bilişim suçlan genellikle ekonomik nedenlerle, maddî çıkar (menfaat) sağlamak amacıyla işlenmektedir. ${ }^{28}$

26 Lloyd, a.g.y., s. 165 .

27 Aydin E.D., a.g.e., s. 14 vd.

28 Aydin E.D., a.g.e., s. 60: "Suçlular genellikle yüksek gelir düzeyinde olmakla birlikte suça iten nedenler yine de ekonomiktir". 
Başka tür bir çıkarın da suçun işlenmesinde etkili olması mümkündür. Örneğin bir oğrencinin okuduğu okuldaki programa girerek kendi notunu deģiştirmesinde olduğu gibi.

Herhangi bir çıkar olmaksızın, ormeģin sadece yardım amacıyla da bu tür fiiller yaygın şekilde işlenmektedir. Programlanın hukuka aykırı olarak kopyalanması ve başka kişilere verilmesinde olduğu gibi. Bu durum, ister suç niteliğinde ister başka hukukî ihlâl - niteliginde olsun bilişim araçları ile ilgili birtakım fiillerin, bunların işleyenler tarafindan meşru kabul edilmesi sonucunda ortaya çıkmaktadır. Gerçekten "Bilişim suçu, bilgisayar alanında çalışan birçok kişi tarafından toplum düzenine aykırı bir davranış olarak tanımlanmakta ancak yasalann ihlâl edilmesi olarak deģerlendirilmemektedir. ${ }^{29}$

Bir başka suç nedeni, bilişim arą̧ ve donanımlan konusunda bilgi sahibi olanlarnn iddialılıklan ve kendilerini isbat çabalarıdır. Bu kişiler, bilgisayan bazan bir entellektuiel meydan okuma araci olarak kullanmaktadırlar. ${ }^{30}$

\section{Bilişim ihłâllerinin çeşitleri}

\section{1. Genel olarak}

Diğer hukuk düzenlerinde oldư̆u gibi bizim hukukumuzda da çeşitli yönleriyle bilişim ihlâllerịni düzenleme gereği duyulmuştur. Yorum yoluyla yapılacak degerlendirmenin ozel hukukuta dahi zorluğu ortada iken, kanunilik ilkesinin geçerli olduğu Ceza Hukuku alanında Kanun Koyucunun hüküm getirerek durumu açıklığa kavuşturması gereği kendisini daha güçlü şekilde duyurmaktaydı.

Ancak bu konuda da, bilişim alanındaki sorunların tam bir değerlendirmesinin henüz yapılamamış olması ve sürekli şekilde ortaya çıkan gelişmeler, sőz konusu olabilecek ve cezalandınlması düşünülebilocek fiillerin hangileri oldugunu net bir şekilde saptamaya imkân vermiyordu.

Buna rağmen, gelişmelerin sonunu beklemek ve ondan sonra düzenleme yapmak gibi bir yol seçmenin doğru olmayacağı açıktı. Gerek diğer ülkelerde gerek bizde kanun koyucular bilişim suçları ile ilgili ceza hükümleri koymak ihtiyacını hissetmişlerdir. Elbette zaman içerisinde bilişim alanındaki fiiller netleştikçe ve yeni gelişmelerin ortaya çıkaracağı fiiller belirginleştikçe, bu yeni fiiller açısından da ceza yaptınmı ile koruma ihtiyacı soz konusu olup olmadığı degerlendirmesi ileride yapılacaktrr.

Çeşitli bilişim ihlâllerinden hangilerinin cezaî yaptırım altuna alınması gerektiği, bir yanda olmasi gereken hukuk (de lege ferenda) ve diger yandan olan hukuk (de lege lata) bakımından değerlendirilebilir.

Birinci yaklaşımda, akla gelebilecek tüm ihlâller gözönünde bulundurulup bunlann tasnife tabi tutulması ve içlerinden ağırlığı veya diğer yapunımlanı yetersizliği nedeniyle suç sayılması gerekenlerin belirlenmesi yoluna gidilir.

\footnotetext{
${ }^{29}$ Aydin E.D., a.g.e., s. 62

- ${ }^{30}$ Aydin E.D., a.g.e., s. 61
} 
Olması gereken hukuk bakımından yapılan bu değerlendirme, ortaya çıkabilecek ihlâllerin en azından tama yakın bir şekilde bilinmesini gerektirir. ${ }^{31}$ Aynca, herbir ihlâlin yaratabileceği zarar veya tehlikenin ve bunlara karşı dił̧er tür yapurımların koruma derecesinin de isabetli bir şekilde değerlendirilebilmesi zorunluluğu vardır. Aksi takdirde, yapılacak incelemede gerçekci sonuçlara vaniması zor olacaktur.

Diğer yaklaşım ise yürürlükte bulunan kanun hükümlerine göre değerlendirme yapılması şeklinde olacaktur. Elbette bu incelemede, suç olarak óngörülen fiillerin teknikhukukî yönteme göre yorumu ${ }^{32}$ yapılarak, unsurlannın belirlenmesi ve kanunilik ilkesi gereģince sunırlarının çizilmesi gèrekecekitr.

Mevzuatımız bakımından, Ceza Kanunumuzda ongơrülen bilişim suçlan ile ilgili hükümlerin Fransız Ceza Kanunu Projesi'nin 307. maddesindeki "Enformatik'e karşı Suçlar" hükümlerinden yararlanılarak hazırlanıp kabul edildiğini ${ }^{33}$ ve saptayabildiğimiz kadarıyla bugüne kadar, Yargitay Kararlar Dergisi ve diger meslek dergilerinde yer alan herhangi bir karara konu olmadıklarını belirtmek gerekir. Bu durum, bilgisayar kullanımının yaygınlaşmaya başlamasıyla ortaya çıkabilecek ihlâlleri yapurım alına almanın haklı kaygısı. içinde kabul edilen bu hükümlerin, genel sistemle bütünleşmiş ve uygulama kaabiliyetine sahip nitelikte olmadıkian kuşkusunu uyandırmaktadır.

\section{2. Ayrimlar}

Bilgisayar (veya bilişim) suçu adı verilen bu kategoriyi deģişik kapsamda anlayanlar vardır. Bazı yazarlar sadece bilgisayarlar aracılığıyla mal varlığına karşı işlenen suçları bu kapsamda görmekte; buna karşı, diğer bazı hukukçular konuyu daha geniş değerlendirerek bilgisayarların her türlü kơtüye kullanımından kaynaklanan suçlan bu kategoriye dahil etmektedirler. ${ }^{34}$

${ }^{31}$ Aydın E.D., a.g.e., s. 47 vd: Ozellikle A.B.D.'nde bilişim alanında ortaya çıkan, bilgisayar ortamını ilgilendiren ve ceza yaptırımı altına alınmasında (suç sayılmasında) gereklilik bulunup bulunmadığı değerlendirmesi yapılan fiillerle ilgili olarak şu örnekleri vermektedir: bilgi aldatmacası, Truva atı, salam tekniği, superzaping (süper darbe). kapan kapakları, logic bombs (mantık bombaları), software bombs (yazılım bombaları). time bombs (saatli bombalar), rabits (tav̧̧anlar), worms (solucanlar), asenkronize saldırı, leş̧̧ilik, veri sızdırma, yankesicilik, taklit, tel salma, simülasyon, modelleme, bug-ware, chameleon (bukalemun).

${ }^{32}$ Ceza hukuku da dahil olmak uzere, hukuk alanında yorum yapılırken, "genişletici" ya da "daraltıcı" yorumdan söz edilmesinin ve özellikle ceza hukukunda "genişletici yorum" yapılmayacağı şeklindeki ifadelerin irdelenmesinde yarar vardır. Bir hukuk kuralı incelenirken, her türlü yorum tekniğinden yararlanılarak o kuralın anlamı belirlenmeye çalışılır. Bu çalışma sırasında kuralın içeriğini, anlamını ve sınırlarının genişletici veya daralıcı bir çaba sarfedilmesinin mümkün olmadı̧̌ıı ą̧ıktır. Amaç, kuralın uygulama alanı ne ise onun belirlenmesidir. Sonuçı bu alanın "geniş" ya da "dar" çıkması, geniş ya da dar olmadigından degil, yorum sonucu bu alanin geniş ya da dar oldugunun saptanmıs olmasındandır.

${ }^{33}$ Erem, a.g.y., s. 441.

${ }^{34}$ A YDIN, O.D., a.g.y., s. 73. 
Genellikle bilişim araçlan ile ilgili olarak üç kategori suçun işlenebileceğinden sőz edilir: 1) bilgisayann maddi konusunu teşkil ettił̧i suçlar; 2) bilgisayarın arą olarak kullanılması suretiyle işlenen suçlar; 3 ) bilgisayar ortamında işlenen suçlar. ${ }^{35}$

$\mathrm{Bu}$ üç kategoride suç bakımından, ceza hukuku sistemimizde kullanılan terimler gőz. onnünde tutularak ve Aydın'ın da ónerdigi şekilde sırasıyla "bilişim sistemleri ile işlenen suçlar", "bilişim sistemlerine karşı suçlar" ve "bileşim araçlanına karşı suçlar" isimlerinin kullanılması daha uygun olacaktur. ${ }^{36}$

tlk iki kategoride yer alan suçlar, yani "bilişim sistemleri ile işlenen suçlar" ile "bilişim sistemlerine karşı suçlar" ın, aralarındaki ayrım herzaman çok net olmamakla beraber, bilişim suçlanının esasını teşkil ettikleri sóylencbilir. Özellikle son kategoride yer alan suçlann, bilişim arą̧ ve gereçlerini hedef almanın otesinde bir özelliģe sahip olmadıkları açıkur. ${ }^{37}$ Bilişim araçlarının güvenliğine karşı suçlar, sistem kullanılmakssızın sadece araçlar ve gereçler hedef alındığında klasik anlamda suçlara góre bir ozellik gðstermezler.

Bilişim sistemleri aracılığıyla işienen suçlann da aslında sadece bilgisayarın sų̧ aracı olarak kullanılması şeklinde bir bzelliģi olduğu, sonuçta araç değişik olmakla beraber zaten mevcut olan suçlann bu araçla işlenmesinin sŏz konusu oldư̆u ileri sürülebilir. ${ }^{38}$ Dolayısıyla, asıl "bilişim suçu" denebilecek suçların, bilgisayar sistemlerine karşı, bilgisayar ortamında işlenen suçlar olduğunu söylemek daha doğru olsa gerektir.

Ancak, bilgisayar aracılığıyla işlenen suçlarda da suç aracının çok özg̈ün nitelikleri ve suçun işleniş şeklini ónemli şekilde etkilemesi dolayısıyla bu kategori suçlar da normal olarak "bilişim suçları" meyanında ele alınmakta; hatta bilgisayara (bilişim aracına) karşı işlenen suçlar da bu ozellikleri dolay!sıyla bu kategori içerisinde mütalaa edilmektedir.

\section{3. Bilişim araçlarına karşı suçlar}

Bilişim araçlarına karşı sưçlar, hukukî açıdan genel olarak ceza mevzuatında mevcut suçlara gơre bir özellik göstermedikleri için üzerlerinde fazla durmakta da bir yarar yoktur.

"Bir terorist grubunun içinde bir bilgisayarın da bulunduğu bir binayı havaya uçurması veya $\mathrm{ABD}$ 'nde bir bankada nöbet sırasında canı sıkılan bir güvenlik görevlisinin bir bilgisayarı hedef tahtası gibi kullanması" gibi haller bu suçlara örnck olarak

35 Lloyd, a.g.y., s. 164. Aydın E.D., a.g.e., s. $28^{\circ}$ de ABD'de yapılan diğer bir tasnifi şöyle aktarmaktadır: 1. Fikir haklarına karşı suçlar; 2 . Bilgisayar donanım ve gereçlerine karşı suçlar; 3. Bilgisayar kullanıcılanna karşı suçlar.

${ }^{36}$ Aydın E.D., a.g.e., s. 27 bu iki kategori suçu "bilişim sistemlerine karşı işlenen suçlar" ve "bilişim sistemleri ile işlenen suçlar" diye ifade etmektedir.

${ }^{37}$ Lloyd, a.g.y., s. 164.

${ }^{38}$ Lloyd, a.g.y., s. 164. Yazar haklı olarak, "Adam öldürme suçunda, kullanılan silahtan ziyade failin davranışına bakıldığı gibi, bilgisayarın kullanılmasının davranısıı hukuka aykıılığının tayininde önemli olmadığı söylenebilir" demektedir. 
verilmektedir. ${ }^{39}$ Zira bu suçlar, ekonomik deł̧eri olan herhangi bir eşyaya veya taşınabilir mala karşı işlenen suçlar niteliğindedir. Bilgisayann veya bir programın çalınmasında veya tahrip edilmesinde oldugu gibi. Bu tür suçlarda normal olarak Ceza Kanunlannın mevcut hükümleri yapurım uygulama bakımından yeterli olacakur. Ancak, bu konuda, uygulama alanı tarışılabilir, olsa da, bizim sistemimizde kabul edilen Bilişim Suçlannda olduğu gibi ơzel hüküm ơngơrülmesi mümkündür (m. 525/b-1).

\section{4. Bilişim sistemleri ile işlenen suçlar}

Yukanda da değinildiği üzere, bilişim sistemleri aracılığıyla işlenen suçlarda, başka bir deyişle bilgisayar sisteminin suç aracı olarak kullanıldığı durumlarda, aracın ozzelliği dışında, yeni ve anlamlı çok az hukukî sorun ortaya çıkacakur.

Burada "bilgisayarın" değil "bilgisayar sistemi"nin suç aracı olarak kullanılmasından söz edişimiz, bu suçların sistemin kullanılması suretiyle işlenmesindendir. Bir cisim olarak bilgisayann suç aracı olması, akla ơrneğin bir kimsenin kafasına bilgisayarın atılarak yaralanmasına sebebiyet verilmesini çağnş̧ırabilir. Buradaki amaç, meşru olmayan birtakım fiillerin işlenmesinde bilgisayar ortamının manyetik - elektronik işlem yapma imkânlanının araç olarak kullanılmasını ifade etmektir.

Lloyd, böyle bir suç için Amerika'daki "Equity Funding" ơmeğini vermektedir. 40 Bir sigorta şirketinin yơneticileri, firma paralarını kendi hesaplarına geçirmişler ve meydana gelen açığın anlaşılmaması için hayali isimlere bilgisayarda gittikçe artan sayıda sigorta poliçeleri düzenleumişlerdir. Para alınmamasına rağmen iş hacminin artmış olması firma hisselerinin değerini arturmıs ve açıkların meydana çıkmaması için sigorta poliçeleri üzerinde devir, temlik ve fesih işlemleri yapılmıştır. Gerçek meydana çıktığında, firma tarafından düzenlenen 97.000 poliçeden 64.000 'inin hayali kişilere ait olduğu anlaşilmışıtır. Buradaki güveni kötüye kullanma fiili aslında genel olarak işlenenlerden farklı değildir. Ancak, bilgisayar yerine elle poliçe düzenlemeye kalkılmıs olsa, suçta temadiyi o kadar süre devam ettirmek mümkün olmayacaktı.

\section{5. Bilişim sistemlerine karşı suçlar}

Bilgisayarın ve bilgisayara dayalı bilişim sistemlerinin ortaya çıması ve yayılması üzerine söz konusu olan suçlar arasında asıl "bilişim suçu" denebilecek suçlann, bilgisayar sistemlerine karşı bilgisayar ortamında işlenen suçlar olduğunu sőylemenin daha doğru olacağını yukanda belirtmiştik. Gerçekten, bilgisayar ortamında bilgisayar sistemine karşı işlenen fiillerin oluşturduğu bu kategori diğerlerine göre daha yeni ve çơzümü daha gụ̧̈ sorunların değerlendirilmsi zorunluluğunu ortaya çıarmaktadır. ${ }^{41}$

${ }^{39}$ Líloyd, a.g.y., s. 164.

40 Lloyd, a.g.y., s. 164.

${ }^{41} \mathrm{Bu}$ tür filllere ömek olarak, verilerin yetkisiz bir şekilde deģ̧ş̧tirilmesi ya da silinmesi veya bilgisayar ortamının sahibinin rızası olmadan kullanılması verilebilir: Lloyd. a.g.y., s. 165 
Diger kategorilerden farklı olarak burada, daha önce mevcut suç filleriyle benzerlik gostermeyen ve daha once mevcut olmayan bir ortam olan bilgisayar ortamında işlenen yeni fiiller sóz konusudur.

"Computer hacking" (bilgisayarda yetkisiz işlem yapma) fiillerinin, bilgisayarların daha yaygın olarak kullanılmasıyla, zaman iģersinde artmakta olduğu bilinmektedir.

Bu fiillerde bazan, fail bir yarar sağlamak veya zarar vermek için değil, marifet gőstermek amacıyla, şifreleri ç̋züp bilgisayar ortamına girmekle yetinmektedir. Sadece bu kadarla yetinilmesi halinde, normal olarak, bu fiillerin işlendiģinin anlaşılması dahi mümkün olmaz, Ancak, bu marifeti gősterenler, genellikle marifetlerinin bilinmesini de istedikleri için, bilgisayar ortamına bu belli edecek bir iz, ziyaretlerini belli edecek bir mesaj birakmaktadırlar. Bir nevi elektronik kirletme (graffiti) sayılabilecek bu filleri cezalandıracak bir hüküm bizim mevzuatımızda bilişim suçları ile ilgili ozel kısımda bulunmamaktadır. Mevcut program veya verileri deł̣iştirme nitelił̌i gơstermediği takdirde $(525 / \mathrm{b}-1)$ suç ơngören hükümlerden herhangi birinin kapsamına bu fiilleri sokabilmek de mümkün görünmemektedir.

\section{III- CEZA HUKUKUMUZDAKI DÜZENLEMELER}

\section{Genel olarak}

Mevzuaumızda ozzel hükümlerin bulunmadığı dönemde de, bugün bilişim suçlan olarak ơngörülen fiillerin cezalandırılmasının mümkün olduğu gőrüşü bulunmakla beraber, daha once de soylendiği üzere, ozzellikle bilgisayar sistem ve ortamında işlenebilen fiiller bakımından, sistemimizdeki kanunulik ilkesine aykın olarak yorum kavramının sınılarını zorlayıp kıyas anlamına gelecek değgerlendirmelerle sorunu çözmeye çalışmak isabetli değildir.

6 Haziran 1991 tarih ve 3756 sayılı Kanunla Ceza Kanununa eklenen 11. Bapta "Bilişim Alanında Suçlar" başlığı alunda yer alan dört maddede (525/a-525/d) suç olarak ongörülen fiiller ve bunların cezalan düzenlenmiştir.

Kanun koyucu bu düzenlemeyi yaparken, bilişim alanında, daha once mevcut olmayan, yeni hukuk ihıâllerinin ortaya çıkığı, bunlardan bir kısmının ceza yapurımına bağlanması gereğinin doğdugu değerlendirmesinden hareket etmiştir. "Bilişim", bilgileri toplayıp depo ettikten sonra bunları otomatik olarak işleme tabi tutma sistemi olarak tanımlanmışur. ${ }^{42}$ Bu tanımın, eloktromanyetik işlem özelliğini ne derece içerdiği tartuşılabilir.

Bu şekilde ơngörülen hükümler, bilgisayar ve bilişim konusunda ozel olarak bazı suçlar öngơrmek suretiyle bu konuđa ortaya çıkabilecek ihlâllere karşı cezaî korumayı ifade etmektedir.

Yeniden öngörülen suçlarla ilgili bu düzenlemelerle, daha önceden mevcut suçlara iliş̧kin düzenlemelerin nasıl bağdaştırılacağı, farklı hükümlerin birlikte uygulanabilirliģi konusu üzerinde durmak gerekir. Gerçekten, bir kimsenini, bilgisayar programlan ile

${ }^{42}$ Aydın, a.g.e., s. 131 . 
komutlar vererek, başkasının zaranıa ve kendi yararına menfaati sał̆laması halinde bu fiili "hursızlık" veya "dolandırilıcık"olarak nitelendirilebiliyorsa, Ceza Kanununun 491 veya 503. maddesi, bilişim suçlarını ongören hükümlerle, orneğin 525/b-2 fikrası ile birlikte uygulanacak midır?

Kanundaki düzenlemenin bu bakımdan netlik taşıdığı, bilişim suçları hükümlerinin diğer hükümlere göre ozzel hüküm niteliğinde olduğu ve genel nitelikteki hükümlerin özel hükümlerle içtima etuirilemeyeceği söylenibilir. Aşağıda bilişim suçlan ele alınırken bu konuda daha ayrnulı bilgi verilecektir.

\section{2. Öngörülen suçlar}

Bu dơrt maddeden ilk ü̧̧inde yer alan suçlar aşał̆daki şekilde suralanabilir:

Bilgileri otomatik olarak işleme tabi tutmuş bir sistemle ilgili olarak:

a) Ele geçime ("Programlan, verileri veya diğer herhangi bir unsuru hukuka aykın olarak ele geçirme") suçu (m. 525/a-1);

b) Tasarruf ("Bir programı, verileri veya diğer herhangi bir unsuru başkasuna zarar vermek üzere kullanma, nakletme çoğaltma") suçu; (m. 525/a-2)

c) Tahrip ("Başkasına zarar vermek veya kendisine veya başkasına yarar sał̆lamak maksadiyla bir sistemi veya verileri veya diğer herhangi bir unsuru kısmen veya tamamen tahrip") suçu; (m. 525/b-1) suçu (m. 525/b-2)

d) Yarar sağlama ("Kendisi veya başkası lehine hukuka aykın yarar sağlamak")

e) Delil tahrifi ("Hukuk alanında delil olarak kullanılmak maksadıla sahte bir belgeyi oluşturmak için ... verileri veya diğer unsurlan yerleştiren veya var olan verileri, diğer unsurlar tahrif etmek") suçu (Lahrif edilmiş verileri bilerek kullanmak fiili dahil); (m. 525/c)

\section{Düzenleme ile ilgili genel degerlendirmeler}

\section{1. Kanun hazırlığı aşaması}

Bu düzenlemelcrle ilgili olarak, mevcut ihtiyaç durumunun isabetli şekilde saptanıp saptanmadığının, ortaya çıkması muhtemel ve ceza yaptınmını gerektirebilecek fiillerin bir sistematik içinde belirlenip belirlenmediğinin ve Ceza Hukuku genel sistemi içersinde tutarlı hükümlere yer verilip verilmediğinin değerlendirilmesi gerekir.

Erem'in belirtiğine göre, "Adalet Bakanlığı'nda hazırlanan Türk Ceza Kanunu tasarısındaki hükümler Fransız Ceza Kanunu projesinden esinlenerek" düzenlenmiştir. ${ }^{43}$ Şimdi artık kabul edilmiş olan Fransız Ceza Kanununun tasarı halindeki hükümlerinin bizim mevzuatımıza alınıken oradaki mantıga ve sistematiğe hangi ölçüde sadık

${ }^{43}$ Erem, a.g.y., s. 441. 
kalındı $\nvdash_{1}$, bundan aynılmak yoluna gidildiyse hangi mantığa dayanıldığı, gerek bu hükümler alınırken ve gerek deģişiklikler yapılırken Ceza Hukukumuzun genel sistematiği ile ahenkleştirme çabası gösterilip gósterilmediği hususuları ayrıca değerlendirilmelidir.

Burada sobyleyebileceğimiz, yine Erem in belirttiği üzere, "projede dört halin sư̧ sayıldığına değinilmiş, bunların 'programa hiyle ile girmek', programda 'casusluk', 'sabotaj', 'ekonomik hiyle' oldugudur.44

Aşağıda görülecę̧i üzere, Ceza Kanunumuzda ơngörülen suçlar kapsamında, ormegin programa hile ile girmek fiilinin suç sayılmasi mümkün deł̧ildir. Bundan, Adalet Bakanlığı tasansı hazırlanırken rahat hareket edildigi, Fransız tasarısının hükümlerinden esinlenilmekle beraber, onun sistematigi ile bağlı kalınmadığı anlaşılmaktadır.

Bu durumda, Ceza Kanununa dahil edilen bu yeni bơlümde yer alan suçlann dúzenlerımesinde hissedilen sistematik noksanlığına ve çelişkilere, en azından kısmen, hazırlık çalışmalarında sebebiyet verildiģi anlaşılmaktadır.

\section{2. Yeni çalışmalarda özen gereği}

Bunu söylerken amacımız, sadece eleştirmek değil, bir uyarıda bulunmaktır. Aşağıda daha ayrıntıli olarak belirtilecey̆i üzere, Ceza Kanunundaki bu hükümlerin yetersizliği ve tutarsızliğı ortadadır. Bu konuda ileride yeniden çalışma yapılması da bize kaçınılmaz gelmektedir. Böyle bir durumda, hukukçularımızın, konunun son derece teknik ve uzmanlık gerektiren yönünü unutmamaları gerekecektir. Bilgisayar kullanan hukukçuların sayısının artmakta olduğu bir gerçektir. Ancak, bu durum, hukukçulara, bilgisayar kullanıcısı olmakla, bilgisayar uzmanı olmak arasındaki büyük uçurumun bilincini de vermelidir. Bu kadar karmaşık bir teknolojinin yaratuğı daha da karmaşık hukuksal sorunlan anlamak, değerlendirmek ve hukuksal koruma mekanizmalarını oluşturmak için iki alanın uzmanlarının ortak çalışma yapmaları şartır. Teknolojideki gelişmelerin son derecede süratle cereyan ettiği, dolayısıyla hukukî tanımlamaların ve belirlemelerin güçleştiği bu alanda, ortak çalışma halinde dahi hukukî değerlendirmelerde büyük zorluklarla karşılaşılması ihtimali vardır.

Sadece sinema filmlerinin çevildiği dönemlerde çekim, dolaşım ve gösterimin denetlenmesi nisbeten daha kolay iken, daha sonra gittikçe küçülen video kasetlerinin ortaya çıkş̧ı nasıı bu düzenleme ve denetimi zorlaşurmışsa; daha önceleri sadece birką̧ radyo ve televizyon istasyonu ile yayın yapılırken daha sonra bunlann yaygınlaşması ve uydular aracılığıla yayın yapılmaya başlanması nasıl bu alanlarda düzenleme ve denetlemeyi sorun haline getirmişse; aynı şekilde bilgisayarlanı ortaya çıkışı ve bu esasa dayalı ve "ortalama insan"ın (uomo medio) anlaması mümkün olmayan sistemlerin ulusal ve uluslararası alanda yaygın şekilde kullanılmaya başlanması hukukun sınırlarını zorlamakta, pek çok yơnüyle düzenlemeyi ve denetimi nasıl yapacaklanını değerlendirmek zorunda olanlan çaresiz birakmaktadır.

Elbette bu durum, bilgisayar alanında da düzenleme, denetleme ve gerekiyorsa cezalandırma amacıyla kural koyma çabalarından vazgeçmeyi gerektirmeyecektir. Ancak 
hukukçunun bilmesi gereken, ठzellikle bu ve benzeri alanlarda, eskiden mevcut sınurlı bireylerarası ve birey-toplum ilişkilerinde olduğu gibi genel bilgilerle hukukusal düzenleme yapılamayacağı gerçeğidir.

\section{3. Geniş düzenleme çabası}

Kanun hükümlerine dönecek olursak, oncelikle, "bilgileri otomatik olarak işleme tabi tutmuş sistem"den sððz edilmek surètiyle ceza kurallannın uygulama alanında geniş tutulmak istenmiş olduğu izlenimi edinilmektedir.

"Bilgileri otomatik olarak işleme tabi tutan" bütün sistemlerin temelini teşkil ettigini söleyebileceğimiz "bilgisayar" kavramının bu düzenlemelerde esas alınmaması kanımızca isabetli olmuştur. Zira, bilgisayar kavramının dar anlaşılması halinde, aynı esasa dayahı sistemlerle ilgili olarak işlenebilecek aynı nitelikteki fiillerin cezasız kalmasına yol açılabilecekti.

Aynı şekilde, ceza yapurımı alına alınması amaçlanan fiiller bakımından da geniş kapsamlı bir düzenleme yapılması çabası gősterilmiştir. Boylece, bilişim sistemleri, verileri ve diğer unsurlan aracılığıyla veya bunlara karşı işlenebilecek ve ne olduklan tam olarak kestirilemeyen filllerin mümkün mertebe sụ̧ sayılması yönünde genel deyimler kullanılmıştir.

\section{4. Cezalandırmada gereklilik}

Bu noktada, bobylesi bir çaba gösterilirken ceza kuralı koymanın temel degerlendirmesi olan gereklilik değerlendirmesinin yapılıp yapılmadıgı, yapıldıysa isabetli şekilde mi yapıldı $g_{1}$ sorusu akla gelmektedir. Elbette, bazı fiillerin meşru olduğu şeklindeki yaygın kanı bu fiillerin suç sayılmaması bakımından gerekçe olamaz. Ancak, bilindił̧i üzere, cezalann bir özellił̧i uygulanmalanının "muhakkak" olmasıdır. Pratikte uygulanacak veya uygulanamayacak olan yapurımlar óngörmek, kâğı üzerinde kalacak suçlar yaratmak ceza hukuku bakımından sakıncalıdır. Ömeğin, bir programı hukuka aykırı olarak ele geçirmeyi yani kopyalamayı suç saymak iki türlü değerlendirilebilir. Bu fiillerin ülkemizde yaygın şekilde işlenmesi dolayısıyla, sadece ozel hukuk yapurımlanyla bu fiillerin önlenemeyeceği anlayışından hareket edilmiş olabilir. Buna karşılık, bu tür fiillerin ortaya çıkarılmasında ve takibindeki zorluklar ve bunların adeta meşru görülmesi şcklindeki genel kanaat sonucu, suçu öngören ceza hükmünün kâğıt üzerinde kalacağı ileri sürülcbilir.

Kısa ifade etmek gerekirse, bilişim alanında ortaya çıkabilecek ihlâllerden hangilerinin bzel hukuk ihlâli olarak bırakılmasının uygun olacağı, hangilerinin ise ancak ceza yaptırımı ile önlenebileceği konusunda yeterince titiz bir inceleme yapılmadan, bazı fiillerin yapturımsız kalacağı endişesi içerisinde, çok geniş ifadelerle suçlar ihdasınında çok isabetli bir davranış olmadığı söylenebilir.

\subsection{Düzenleme dışında kalan fiiller}

Buna karşllık, gerek sőz konusu hükümlerinin kabülü sırasında işlenebildiği bilinen fiiller gerek bunların kabulünden bu yana geçen zaman içerisinde ortaya çıkan yeni gelişmeler ve bunlara bağlı ihlâller açısından yine de suç olarak kabul edilebilecek birtakım fiillerin bu düzenleme dışında kalıp kalmadığı değerlendirmesi de yapılabilir. 
Aşağıda daha yakından incelendiklerinden görülecę̆i üzere, mevzuata dahil edilen bilişim suçları esas itibariyle "bilişim sistemlerine karşı suçlar" katogorisine giren fiilerden oluşmaktadır. Sadece 525/b-1 fıkrasındaki suç bakımından "bilişim sistemleri ile işlenen suçlar"la ilgili bir düzenlemenin de yapılmış oldư̆u sőylene bilir. Buna karşılık, başka birkısım fiillerin benzer niteliklerine rağṃen suç olarak kabul edildikleri soylenemez.

Gerçekten, ormeğin bir bilgisayar sistemine izinsiz. girilmesi fiili Ceza Kanununda suç olarak ơngörülmemiştir. Böyle bir sisteme izinsiz girip programın "tahribine" yol açan kişi de, şayet "başkasına zarar vermek veya kendisine veya başkasına yarar saglamak maksadıyla" hareket etmemişse yine bu maddelere góre cezalandırılmayacaktır. Fiillerin taksirli şekilde işlenmesi ơngőrülmedił̧i için, ózellikle fail programa girmek istemekle beraber programlan istemeden zarara uğratmış ise bu fiil dahi cezalandırma kapsamı dışında kalacaktur.

\section{6. Sistematik değerlendirmede zorluk}

Bu bőlümde yer alan maddelerin ơngördügü fiillerin belli bir sistematik içerisinde değerlendirilmesi mümkün değildir Daha önce yapmı̧ olduğumuz genel üçlü tasnif içerisine yerleştirilmeleri büyük zorluk gősterdiği gibi, kendi mantıklan içerisinde tutarlı bir sisteme yerleştirilmelerini de biz sağlayamadık. Diǧer maddelerde öngörülen fiillerle karşılaştırma yapıldığında ve yaptırımlann mahiyeti ile fiillerin ağırlığı gőz önünde bulundurulduğunda ortaya çıkan çelişkiler bu zorluğu arttımaktadır. çalışacağz.

Sơz konusu suçlar ayn ayn incelenirken bu yönden de bir deł̆erlendirme yapmaya

\section{Suçun hukukî konusu}

Bilişim suçlan genel olarak ekonomik bir yarar ya da zarar saglayan mahiyetleri itibariyle bir tür "ekonomik suç" kategorisi olarak kabul edilmektedir. Kanun Koyucu, Bilişim Suçları bơlümünde yer alan maddelerde, genellikle, "başkasına zarar vermek", kenđisine veya başkasına yarar saglama" şcklinde ózel kası belirlemek suretiyle suçlann ekonomik niteliğini vurgulamak istemiş görünmektedir.

Kanunda bu suç kategorisine, Mal aleyhine Cürümler Babını takiben yer verilmiş olmasının, hukukî konunun saptanmasında, belirleyici olmamakla beraber, bir anlamı bulundựu kanısındayız. Bu fiiller suç olarak kabul edilirken genel 'olarak korunmak istenen menfaatin, kamu ekonomisi değil, bireyin mal varlığı olduğu anlaşılmaktadır. Kanunda öngörülen suçlar ayn ayn ele alındığında da, 525c maddesinde öngörülen suç dışında, korunmak istenen menfaatin aynı nitelikı olduğu görülmektedir.

525/a-1 fikrasında öngörülen suç bakımından, yarar sağlama veya zarar verme amaçlarından sőz edilmemiş olmasına rał̌men, sistemdeki programları, verileri veya herhangi bir unsuru hukuka aykırı olarak ele geçirmek fiili ya bir kimseye zarar verecek veya başkasına yarar sagllayacaktır. Diger hükümlerde, yani Kanunun $525 / \dot{a}-2,525 / \mathrm{b}-1$ ve 2. fikralarında iş bu amaçlar açıkça belintilmiştir. Ayrıca, söz konuśu hükümlerde kişinin mal varlığının ötesinde, kamu ekonomisinin koruma konusu yapıldığına işaret sayılabilecek herhangi bir unsur da yer almamaktadır. 
Buna karşılık aynı değerlendirmeyi 525/c maddesindeki suç bakımından yapamayacağımız kanısındayız. Zira bu maddede kamunun itimadına ilişkin bir menfaatun koruma konusu yapılmak istendiģi anlaşılmaktadır. "Hukuk alanında delil olarak kullanılmak maksadıyla sahte bir belgeyi oluşturmak için" bilgisayar ortamını kullanan kişinin cezalandırılması, sahtekârlık cürümlerindeki ile aynı nitelikte bir menfaatin korunmak istendigini ortaya koymaktadır.

\section{Suç fáili}

Suç faili herhangi bir kimse olabilir. Bu arac, gerec ve donanımlara karşı, omeğin tahrip şeklinde bir fiilin işlenmesi bakımından failin herhangi bir kişi olabilece ği açıkur.

Ancak, bilişim araçlanndaki bilgilere ve işlemlere karşı veya bilişim araçlanındaki bilgi ve işlemler aracılığıyla işlenecek suçlar bakımından failin bu konuda en azından belli düzeyde bilgi sahibi bir kimse olması gerektił̧inde kuşku yoktur.

Bu bakımdan, bilgisayar suçlan, faillerin genel nitelikleri itibariyle, "beyaz yaka suçu" (white-collar crime) kategorisine dahil saylmaktadırlar. 45

Suç failinin sıfatı ve sự faili ile mağdur arasında iş ilişkisi bulunması fiile uygulanacak ceza bakımından onem taşıyacaktır. Ceza Kanununun 525/d maddesi uyarınca $525 /$ a ve $525 / \mathrm{b}$ maddeleri hükümlerini "meslek icrası sırasında veya icrası dolayısıyla" ihlâl eden memurlar hakkında ek ceza olarak alu aydan ų̣̈ yıla kadar suçun işlendiģi kamu hizmetinden yasaklanma cezası uygulanacakur.

Kişi, memur olmayıp, $525 /$ a ve $525 / b$ maddelerindeki fiilleri özel hizmet ilişkilerinin icrası sırasında veya icrası dolayısıyla işlemişse, ek ceza olarak kendisine alı aydan ü̧ yıla kadar meslek, sanat veya ticaretten men cezası verilecektir.

\section{Suç mağduru}

Bu suçlarda suçun mağduru, 525/a ve 525/b maddelerinde koruma konusu edilen mal varlığına iliş̧kin menfaatin sahibi olan kişi ya da kurulus olacakur. Buna karşıllk 525/d maddesinde ơngörülen suç kamunun itimadına yönelik olduğu için, suç mağduru da kamudur.

Bilişim suçlannda suç mał̧duru bakımından ơzellik gösteren durumlar, mağdurun menfaatının zarara ugratılması ya da tehlikeye maruz bırakılmasının bir makine aracilığıyla olmasından ileri gelmektedir.

Bilişim aracı sisteminin kullanılması suretiyle işlenen fillerde, orneğin bir banka bilgisayar sistemine şifre çözerek hukuka aykın şekilde giren bir kimsenin kendi hesabına başka müşteri hesaplanndan veya banka hesabından para aktarması halinde, yabancı uygulamada hukuka aykın davranışın yöneldiği hareketin muhatabının bir makine olması bakımından bazı değcrlendirmelere girilmesi gereği duyulmuştur. 
Bu meyanda, aldatma, hile (Jiception) unsurunun yer aldıłı suçlarda sadece makinenin şifresinin çözülmesi ve hukuka aykın girişin bı unsuru oluşturmayacăłı, hile veya aldatmanın insana karşı yơnelm

Makinenin sistemine hile ile girilmesinin kişiye karşı hile olarak kabul edilmesinin mümkün olmadığ Ingiliz Mahkeme kararlarında da belirtilmektedir. ${ }^{46}$

\section{Suçun maddi konusu - Suçun aracı}

\section{1. Genel olarak}

Bilişim Suçları bollümündi yer alan suçlar bakımından ortak kavramlar niteliğindeki "bilgileri otomatik olar kl işleme tabi tutmus sistem", "program", "veri" ve "diger herhangi bir. unsur" kavramları konusunda once bazı genel degerlendirmeler yapmakta yarar vardur.

Maddelerde ongórülen suçla- incelendił̧inde, fiillerin mutlaka elektronik bilgi işlem süreci ile baģlantılı olarak: işleı ınesi veya bir bilgisayar kallanımı biçiminde ortaya çımasi $^{47}$ gerekmediği, ömefin sis eme, verilere veya diğer unsurlara yönelmiş tahrip fiillerinin de suç olarak kabul edildi nörölmektedir.

Kanun bir maddesinde digerl esiyle birlikte sistemi $(525 / \mathrm{b}-1)$, bazı maddelerinde sistemde yer alan programlar, verileri ve diger unsurlan (525/a-1, 525/a-2, 525/c) korumaya çalışmışur. Bu kavram :aınn, yani sistem, program, veri ve dið̧er unsur kavramlannm bilgisayar alanınclaki bi]gilere göre değerlendirilecełợ kuşusuzdur.

Bilişim araçlan manyetik-elel dronik ortàmda çalışin araçlar olduklan için, bunlara karşı veya bunlar aracılığyla işlen fil filler de soz konusu ortamlan ve bu ortamlarda mevcut bilgi ve işlemlerin konus ^ olan menfaatleri hedef almaktadı. Dolayisıyla,

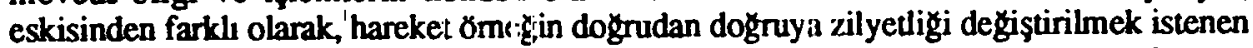
paraya deģil onu temsil eden veri re yönelmektedir. Ancak sonuçta konu ya da araç bilgisayar olsa da hedef o verinin tes asil ettiği menfaat olınaktadır.

Bu durumda, bir fiil bilgisay: ra, sistemine, program veya verilerine ya da diger bir unsuruna karşı işleniyorsa, suçun maddî konusunun çalı̧̧an bir bilgi-işlem sistemi olarak bilgisayar (bilgisayarla çalışan sister nier, programlar, veriler ve diğer unsurlan veya başka bir deyişle bilişim sistemleri) oldu sunu sb̉yleyebiliriz. Buna karşılık, suçun bilgisayar aracılığıla, onun sistem, progranı veya verileri ya da başka bir unsuru aracılığyla işlenmesi halinde bilgisayan:n "sı çun vasıtası" olarak kullanılması hali sơz konusu olacaktur.

525/a-1 fikrasında öngörülerı ele geçirme suçunda sistemde mevcut program, veriler veya diğer bir unsur suçun rıaddi konusunu oluşturacakur. Buna karşılık $525 / \mathrm{b}-2$ fıkrasında sistemin kullanılması suretiyle "hukuka aykırı yarar" saglanması öngörüldügünden, sistem bu yararlanmanin aracı niteliğinde olacakur.

${ }^{46}$ Lloyd. a.g.y., s. 170

${ }^{47}$ Aydın, O.D., a.g.y., s. 73. 


\section{1. 1. "Sistem" kavramı}

Sistem, kanunda "bilgileri otomatik olarak işleme tabi tutmus bir sistem" olarak tanımlanmaktadır. Ancak bu tanımın koruma konusunu net bir sekilde ortaya koyduğu kuşkuludur. "Sistem", genellikle belli bir işlevi olan "donanım" (hardware) ve "yazılım" (software) birimlerinin birleşimi olarak tanımlanmaktadır. ${ }^{48}$ Bobyle olunca, sistemi bir bütün olarak anlamak gerekecektir. Yani sistemden sobz edildiği yerde, sadece bilgisayann içerisinde mevcut işletim programlannın oluşturduğu ortamı ve unsurlanı dȩ̣il aynı zamanda donanımı da anlamak gerekecektir. Donanum ise nesneleri, fiziksel yapıyı, yani klavye, disket sürücü, ekran gibi unsurlan ifade etmektedir: ${ }^{49}$ Bu saptama, aşağıda belirtileceği üzere, sistemde yer alan "diğer herhangi bir unsur" kavramının belirlenmesinde onem kazanmaktadir.

Ceza Kanununu ilgili maddeleri bilişim suçlan bakımından oncelikle "bilgileri otomatik olarak işleme tabi tutmuş sistem" kavramından hareket etmektedir. Suçun maddi konusu bu sistem ya da bu sistemde yer alan programlar, veriler veya diger unsurlardır. Kanun koyucu, suçun madđî konusunu belirlerken sistem, program ve veriler kavramlarıyla yetinmemiş, yeterli korumayı sağlayabilmek amacıyla, bunlanın dışında kalabilecek başka bażı "unsur"lannn da suçun maddî konusu olabileceğini kabul etmiştir. Bu unsurlann neler olabileceği uygulamada ortaya çıkabilecek ihtiyaçlarla belirlenecektir.

Ceza Kanunumuzda öngörülen bilişim suçları bakımından, yeterince net bir şekilde olmamakla beraber, gerek fiziksel yapısı itibariyle bilişim araçlarına karşı fiillerin $(\mathrm{m} .525 / \mathrm{b}-1)$, gerek bilişim sistemleri aracılığıyla işlenen fiillerin $(\mathrm{m} .525 / \mathrm{b}-2,525 / \mathrm{c})$, gerek elektro-manyetik ortam olarak bilişim sistemlerine karşı fillerin (525/a-1, 525/a-2, 525/b-1) ceza yaptırımı aluna alındığı görüyoruz.

\section{1. 2. "Program" kavramı}

"Program", tanımlı bilgileri işlemek ve çıkulan elde etmek amacıyla belli bir işi bilgisayara yapurabilmek için tasarlanmı bir dizi komut olarak tanımlanmaktadır 50 .

\subsection{3. "Veri" kavramı}

Buradaki anlamda "veri" (data) ise, bilgisayar tarafından iletişim, açıklama ve işlem amacıyla herhangi bir amaç, konu, durum, koşul, fikir ya da dịger unsurları açuklamak için kullanılan sayılar, harfler, simgeler belirmek üzere kullanılan genel terim olarak ifade edilmektedir 51 .

\subsection{4. "Diğer unsurlar" kavramı}

Bu maddelerde kullanılan "diğer herhangi bir unsur" deyiminin anlamının yeterince net olduğu ve kapsamın tayinde güçlük çekilmeyeceği sőylenemez. Bu deyimin kullanılmasına yol açan ihtiyacı anlamamak mümkün deģildir. Bilgisayardaki unsurlanın

\footnotetext{
${ }^{48}$ Gürsel-Gürsel, a.g.e., s. 317; Kurtaran-Çubukçu, a.g.e., s 157.

${ }^{49}$ Gürsel-Gürsel, a.g.e., s. 157.

50 Kurtaran-Çubukçu, a.g.e., s. 143.

51 Kurtaran-Çubukçu, a.g.e., s. 177
} 
çok karmaşık olması sonucu, belli unsurlan isimleriyle verdikten sonra, tasanyı hazırlayanlar tarafindan isimleri ve ne oldukları bilinemeyen veya o zaman mevcut olmayıp da sonradan ortaya çıkabilecek olan başka unsurlara da bazı fiilerin yơnelebileceği endişesi dogmuştur. Junu da genel nitelikte "dił̧er herhangi bir unsur" deyimiyle karşılamaya çalışmışlardir.

Burada oluşturulmak istenen koruma, donanıma, yani bilgisayann klavye, disket sürücü, ekran gibi fiziksel kısım! anıııı değil, ozellikle bu âletlere bilgi depolama ve bilgiişlem yapma yeteneł̧i kazandıraı yapısal programlara yöneliktir.

Fiziksel unsurlan ile bilgisayarı koruyacak yeterli hükümler Ceza Kanununda zaten mevcut olduğu ve bilgissiyar sistemleri bakumından bzellik gosteren korumanın bilgi-işlem yapısına yönelen fiil erle ilgili koruma olması gerektiłgi için düzenlemenin bu şekilde olması da isabetlidir. Aıccak Ceza Kanununda bu suçlarla ilgili düzenlemelerde kullanılan terimler farklı bir anlıyıı̧ıı ortaya atılabilmesi olasılığını ortaya çıkarmakıadır.

Bir hükümde (525/b-1) "kısmıen veya tamamen tahrip" deyiminin kullanılması, fillerin bazı hallerde bilgisayarm fiziksel oğelerine de yőnelebileceği yorumuna yol acabilecektir.

Boyle bir yoruma, yukarıda "sistem" kavramı ile ilgili olarak yapılan açıklamalar da destek verebilecektir. Bilişirn suçlan ile ilgili değerlendirmeler yapilurken bu alanın kavram ve tanumlarundan harel.et edilmesi gerektiği kuşkusızzdur. Bu alanda "sistem" denince anlaşılan yalnız yazılım dę̧,il aynı zamanda donanım olduğu için, Kanunda sistemle ilgili "diģer herhangi bir unsur" dendiģinde, şayet kanunun orngördügüu fiil fiziksel bir unsura da yönelebile:ek nitelikteyse, donammın bir parçasıının da suçun maddî konusunu oluşturacağı ileri sürülebilecektir. Gerçekten, "herhangi bir unsuru kasmen veya tamamen tahrip" suç sayıldıł̆ında (525/b-1), ömeğin bilgisayar ekranını parçalamamn da bu kavrama ginliłg iddiasıyla karşılaşmak mümkündür.

Bunun gibi, "sistemden ... herhangi bir unsuru hukuka aykın olarak ele geçiren" kişinin cezalandurılacağını ơngı̈ren hükïm (525/a-1) karşısııda, artuk Kanınun 491 ve sonraki maddelerinde yer alan hırsıl.lıkla ilgili hükümlerin, sadece bilgisayar programı aracılıgıyla yapılan işlemle hak edilmeyen bir paranın alınması halinde değil, ömeğin bir bilgisayar "fare"sinin (mouse) çalınması halinde de uygulanacağı şeklinde anlaşılması tehlikesi vardır. Başka bir deyişle, burada, bir kimse bilgisayarın bir parçasını çaldığı takdirde artık 491. maddeye gö:e de iddiasına yol açabilecek bir düzenleme mevcuttur.

Kanun Koyucunun ama:ının tu olmadığı kanısındayız. Ancak terimlerin özenle seçilmemesi, teknik sözcüklerin yeterince bilinmemesi gibi nedenlerle sonuç amacı aşmı§ görünmektedir.

Kanunun gerekçelerinde de bu konuya, yani Kanun Koyucunun asıl amacının ne olduğuna ışık tutacak açık bir bilgige rastlamamaktayıı. Ancak Adalet Bakanlıł̆ı'nın şimdiki 525/a-1 fıkrası ile ilgili ve genelde madde hükmünün tekrarı şcklindeki gerekçesinde, bu "madde bilgileri otomatik olarak işleme tâbi tutmuş bir sisteme 
(Bilgisayarlara) yerleştirilmiş programlan, verileri veya diğer herhangi bir unsuru hukuka aykun olarak ele geçirmeyi cezalandurı" denmektedir 52 .

Üzerinde durduğumuz konu bakımından ilginç olabilecek bir unsur, "yerleştirilmiş" sőzcügüđür. Bơyle alındığında, ifade "sisteme yerleştirilmiş ... digerer unsurlar" şekline donüşmekte ve fiziksel aksamın bu kavram dışında bırakılmak istendiģi anlaşılmaktadır ${ }^{53}$.

\section{Suçun işlenme zamanı}

Bilgisayarlardaki işlemlerin saniye ve saniyenin bőlümleri gibi çok kısa zaman parçalarında yapılmasına rał̧men, suç işleme zamanı açısından ozel ve farklı bir durum ortaya çıkığı söylenemez. Yine bir icra hareketinin yapılması ve Kanun ơngơrmüşse bir sonucun ortaya çıkması sőz konusu olacak ve suçun işlenme zamanı Ceza Hukukunda yapılan genel değerlendirme ölçütleri çerşevesinde olacaktur.

"Ani suç" dediğimiz suç türünde de hareketin yapılmasıyla sonucun ortaya çıkması hemen hemen aynı zamanda olmakta; daha dogrnusu hareketin yapılmasıyla sonucun ortaya çıkması arasında', ceza hukuku bakımından ónemli olmayacak kadar kısa bir zaman geçmektedir. Bilişim suçlanında bu zamanın daha da kısalmış olması söz konusudur.

Bu durum, suçun işlenmesinde bir kolaylık unsuru olarak değerlendirilebilirse $\mathrm{de}^{54}$, suçun işlenme zamanın saptanması bakımından herhangi bir özellik gőstermez. Belki, suçun işlenme zamanının sağlıklı olarak saptanmasında, bazan kolaylık bazan ise içinden çıkılmayacak bir zorluk yaratabilir. Sayet işlemin yapılışı, sistemde mevcut bir zaman saptama özelliği dolayısıyla kayda geçmişse kolaylık; böyle bir saptama özelliği yok veya bu ozellik devre dışı bırakılmışsa zorluk söz konusu olacaktur.

Bir haksız sonucu gerçekleşirmek için ozel olarak hazırlanan bilgisayar programı, içeriği gereği, belli bir zamanda devreye girip bir işlemi gerçekleştirmiş ve kişi bu işlem sonucundan yararlanmışsa, bu süreç içerisinde, klasik aynma göre icra hareketleri ve sonuç değerlendirmelirini yapmak ve bu şekilde suçun ne zaman işlenmiş olduğunu saptamak gerekir.

Bir Ingiliz Mahkemesinin R v Thompson (1984) davasında yapmış olduğu değerlendirme oldukça ilginçtir ve bizim sistemimiz bakımından da üzerinde düşünülmesi gereken sorunlara değinmektedir: 55

52 Erem, a.g.e., s. 442.

53 Olkemizde kanun tasarıları hazırlanırken genellikle önerilen hükmün tekrarından baska birşey içermeyen gerekçeler verilmektedirler. Kuşkusuz bu kolay olan yoldur ve gerekçe hazırlamak gibi ciddi zihinsel emek isteyen zahmetli bir işi geçiştirmeye olanak są̧lar. Bu durum, genellikle bizdeki kanunların, maalesef konunun ciddiyetini yeterince kavramayan kişilerce. üzerinde fazla düşunmeden, mevcut kurallarla bağdaştırma çabası duyulmadan rastgele fıkarıldıgının bir kanıtıdır.

54 Aydin, a.g.e., s. 57.

$55_{\text {Lloyd. a.g.y.. s. } 166 .}$ 
Thompson bir Kuveyt bankasında bilgisayar programcısı olarak çalışmakta iken, banka bilgisayar sistemine, uzun zamandir "işlem gormeyen" (dormant) hesapları saptadıktan sonra bu hesaplardan kendisinin bankada açtığı hesaba havale yapması komutunu veren bir program ha:ırlamışur. Ayrica bu proģram, Thompson'un bankadaki görevi bitip Ingiltere'ye döndükten sonra devreye girmesi ve işlemleri yaptuklan sonra kendi kendisini silmesi komutlar.nı da icermekteydi.

Thomsop Ingiltere'ye dondü̧ünde, bir bankada hesap açıp, Kuveyt'teki bankaya hesaplarındaki paralann Ingittere'deki hesabına gönderilmesi talimatunı vermiş ve yaklaşık 45.000 sterlinin hesabuna geçmesini sał̆lamışur. Ancak, programun kendi kendini silme kısmı çalışmamıs olacak ki, durum ortaya çıkmış ve Thompson Ingiltere'de yargılanıp dolandinclik suçundan (offence of obtaining property by deception) mahkûm olmuşur.

Thompson bu karara karşı kanun yoluna başvurusunda, filin işleniş sekli ile ilgili bir itirazda bulunmamıs, ancak varsa herhangi bir suçun Ingiltere'de değil Kuveyt'te işlenmiş olduğunu, dolayısıyla Ingiliz Mahkemesinin bu konuda yetkili olamayacağını ileri sürmüştür. Mahkeme, suç teşkil eden fiilin, Kuveyı bankasının hesaplarında değişiklik yapıldığı zaman değił orada temsil edilen değerlerin failin zilyetliğine geçtiği zaman tamamlanmış sayılacağı gerekçesiyle başvuruyu reddetmiştir. Mahkemeye göre, suçun hesaplardaki paralarm Ingiliz bankasina havale edilip bunlar üzerinde Thompson'un doğrudan fiziki kontrol satibi olması sağlandığ zaman işlendiğinin kabulü gerekmektedir.

Bu karar eleştirilmiş ve eski zamanun elle kayıt yöntemleriyle paralellik kurarak yapılan değerlendirmeler sonucu, ancak elektronik alacak bakiyesinin kişinin eline nakit olarak geçtiği zaman fiilin işlenmiş sayılacağı anlayışının bugünün teknolojisi ile bagdaşmadigs belirtilmiştir. ${ }^{56}$

Bu tiil, bilgisayar sistenueri ile işlenen suçlar kategorisine bir ómek teşkil eder. Şahıs, hursızlık ya da dolandınılik kapsamına girebilecek bir fili, bilgisayar sistem ve ortamının ozelliklerinden yararlınarak deģişik bir şekilde işlemektedir.

Sadece programın hazıranması bir hazırlık hareketi olarak kabul edilse dahi, bu programın banka bilgisayan devresine, sonradan harekete geçmek üzere, sokulması davranışı icra hareketi başlamışur. Ondan sonraki aşamada, banka bilgisayar sistemi, failin icra hareketinin bir vasıtisı olarak kullanılmıs olmaktadır. Telefonda bir kimseye hakaret edilmesinde nasıl telefon sistemi failin hakaretamiz sözlerini nakleden bir araç niteliğinde ise, fail tarafından hazırlanan programın bilgisayarın birtakım işlemleri yapması komutunu verip banka bilgisayarında gerçekleştirmesi de aynı anlama gelmektedir.. Mahkeme karar:na göre, banka bilgisayarının verilen komutlara uygun olarak başka hesaplardaki parıları failin hesabına aktarması ile icra hareketleri devam etmekte ve failin hukuka aykırı olarak hesabına geçirttiği parayı Ingiltere'deki banka hesabına havale ettirip almasıyla suç tamamlanmaktadır.

Failin Ingiliz kanununun Kuveyt'te işlenen suça uygulanamayacağı şeklindeki iddiası, aynıca, deģişik kanunların, uygulama alanlarının sapıanmasında farklı ya da aynı ólçütlerden yararlanılması ve sonuçlarının iyi değerlendirilmemesi halinde olumlu ve

56 $6_{\text {Lloyd, a.g.y., s. } 167 .}$ 
olumsuz yetki uyuşmazlıklanının çıkması ve olumsuz yetki uyuşmazlığı halinde, bilgisayar suçları bakımından da "cezasızlık limanlan" (crime havens) yaratılması sonucunu dogacă̆ gençeğini anımsatmaktadır. ${ }^{57}$

\section{Suçun işlenme yeri}

Elektronik sinyallerle ve komutlarla saniye ve saniyenin boblitmleriyle olçülebilecek zaman parçalarında büyük mesafelere ulaşan işlemlerin söz konusu olması dolayısıyla, suçun iş̧lenmesinde klasik suç işleme yeri kavramından farklı bir gơrüntu ortaya çikıyor gibi görünmektedir. Ancak, sonuçta yine insan hareketi ve buna bir âletin araç kılınması sóz konusu olmaktadır. Bu bakımdan, suçun işlenme yerinin saptanması hareketin yapıldığ olçütlere göre yapilacaktur.

Belki burada sơz konusu olan özellik, sınırą̧ın suçlann eskisine oranla daha kolay ve yaygın bir şekilde işlenebilmesidir. Ancak bu durum sınıraşın suçlanın eskiden de bulundugu ve gerek ulusal düzeyde gerek uluslararası düzeyde onemli usul hukuku sorunlarına yol açuklan ve bu sonunlann çozzümü için gerek iç hukuk metinlerine gerek uluslararası metinlere hükümler konulduğu gerçeğini unuturmamalıdı. 58

Bilişim araçlan nedeniyle sınıraşın suçlann daha kolaylaşmış ve daha çok işlenir hale gelmiş olması, yeni usul soranlan çıkarmaz; olsa olsa bu sorunlara yeni ozellikler kazandırır, daha kısa sürede, daha çok ve daha çeşitli şekillerde işlenen bu suçlara mücadele ihtiyacını arturabilir. Yoksa hukukî bakımdan eskiden mevcut sınıragıın suçlar ile bu suçlar arasında bir mahiyet fark yoktur. Fark sadece kullanulan arą̧ yơntunden soz konusudur.

Ancak bu da hukukî değerlendirme bakımından bir ơnem tą̧ımamaka; suçluluğm onlenmesi için yaplacak de gerlendirmelerde gơz onünde tutulacak bir husus olarak ortaya çumaktadir.

Bilgisayar sistemlerinin, omeğin bankacılıkta kullanlanlar, çok kısa bir zaman parçası içinde, gerek bir ülkenin tüm yüzeyine yayılan işlemleri gerek uluslararası alanda birçok ülkeye ilgilendiren işlemleri gerçekleştirebilmektedir. Bunun sonucu olarak, bir ülkede birden çok yetki alanın ilgilendiren sınıraşın suçlar (mesafe suçlan) $)^{59}$ veya birden fazla Devletin hukuk alanlanni ilgilendiren uluslararası sınıraşın suçlar daha kolay ve daha yaygın bir şekilde ortaya çıkabilecektir.

Işlenen bir fiilin, bir ülkenin ceza kuralının yer bakımından uygulama alanına girip girmediğinin değerlendirilmesi, suçun işlendiği yerin saptanması ile mümkün olacakur. Bu bakımdan hareket ve sonucu itibariyle suç teşkil eden fiilin hangi cơ̆rafi alanda işlendigini saptamak, bu alanın bir Devletin hukuk alanı içerisinde mi kaldığını,

57 Lloyd, a.g.y., s. 168.

58 Aydin, a.g.e., s. 59.

${ }^{59} \mathrm{Bu}$ tür suçlarda asıl ayırıcı unsurun hareketle sonuç veya hareketin parçalanı arasındaki zaman farkı veya yer farkı değil, bunlar arasına giren bir yetki veya hukuk alanı sunın olduğu için "mesafe suçu" deyimi yerine "sınırą̧ırı suç" demenin daha doğru olacağını düşunilyoruz. 
yoksa birden fazla Devletin hukuk alanını $\mathrm{m} ı$ ilgilendirdiģini belirlemek gereklidir. Burada varılacak sonuca ve Devletin ceza kurallannın uygulama alanını belirleyen kurallarına göre o Devlet mahkemelerinin yargılama yetkisinin bulunup bulunmadığı açuklığa kavuşacakur.

Yukanda sozzả edilen $\mathbf{R} \mathbf{v}$ Thompson olayı ile ilgili açıklamada belirtildiği gibi Thompson, hakkında verilen matıûmiyet kararına itiraz ederken suçun işlendiği yeri Kuveyt olduģunu, dolayısıyla lngiliz mahkemesinin kendisini yargılamaya yetkili olmadı̆ı̆nı ileri sürmüștür. Mahkeme, suçun, Kuveyt barıkasının hesaplanında deģişiklik yapıldığı zaman değil, orada temsil edilen değerlerin failin zilyetliğine geçtiği zaman işlenmiş kabul edilmesi gerektiği, dolayısıyla suçun Inģiltere'de işlenmiş olduğu sonucuna varmışur.

Bunu yaparken, Thompson'un hesaplardaki paralarin Ingiliz bankasina havale edilmesi talebini Ingiltere'de yaptığını ve paralara orada zilyet olduğunu gerekçe gőstermiştir.

Bir an için aynı fiilin bir 'Türk vatandaşı tarafından ve paranın Türkiye'deki bir bankaya getirilmesi şeklinde işlındiğini varsayarak degerlendirme yapacak olursak, oncelikle bunun hangi suçu oluşturabileceğini değerlendirnnek gerekir. Isabeti aynca tartş̧ılabilir olmakla beraber, Kanunda bu konuda ơzel hüküm konulmuş olduğu için, artık hırsızlık mı dolandıncclik $\mathrm{m}$ ı olacağı şeklinde değerlendirmelere girmeye gerek kalmamıştır. 525/b-1 fıkrası "j'arar sağlamak" amacıyla sistemin yanlı̧ biçimde işlemesini sał̆lamak fiilini suç kabul etmiştir. Buna karşılık 525/b-2 fikrası bరyle bir sistemi kullanarak "hukuka aykın yarar sağlayan" kimseyi cezalandırmışur.

Kanunda 525/b-2 fikrasında tanımlanan haksız "yarar sał̆lamak" suçu, "yarar saģlama" kavramına verilecek anlama göre, Kuvety'te veya Türkiye'de işlenmiş sayılabilir.

Kuveyt'te bilgisayarın yanlı̧ biçimde işlemesinin sa̧̧lanması ve failin hesabına paranın aktarılması ile yarar sağlanmış sayılacak olursa suç Kuveyı'te tamamlanmış olacaktur.

Bu durumda, bir Türk vatandaşı tarafından yurt dışıında işlenmiş bir suç söz konusu olacak ve 525/b-1 fikrasının bu suç için öngördügü hapis cezasının aşağı haddi (bir yıl) Ceza Kanununun 5/1. fıkrasının re'sen takip için öngördügü sınırın (üç yıl) altında olduğu için, $5 / 2$. madde hükmü uyarınca takibat, ancak ;arar gören kişinin veya yabancı Hükümetin şikayeti üzerine yapılabilecektir. Bu durumida, işlenmiş suçtan elde edilmiş olan paranın aynca Türkiye'ye havalc edilmiş olması ayrı bir suç oluşturmayacakur.

Ancak, şayet "yararlanma"nın yabancı ülkedeki banka hesabına yatırılmasıyla gerçekleşmeyeceł̧i, ancak kişinin paraya zilyet olmaș halinde "yararlanma"dan soz edilebilece fi kabul edilirse, bu takdirde, haksız şekilde elde edilmiş bu paranın daha sonra Türkiye'deki bir hesaba nakli ve burada alınması üzerine suç Türkiye'de işlenmiş olacak ve 525/b-1 fikrasina göre Türkiye'de re'sen takip edilecektir. 


\section{525/a Maddesindeki suçlar}

Bu maddede ongơrülen suçlar, daha once yapılmıs olan tasnifte "Bilişim sistemlerine karşı suçlar" diye ifade edilen bilgisayann elektro-manyetik ortamında işlenen fiillerin bazılannı kapsamaktadır.

Bu suçlann mądđî unsurlannı oluşturan "ele geçirmek" (525/a-1) ve "kullanmak", "nakletmek" veya "çoğaltmak" fiillerini ayn ayn ele alıp incelemenin pratik bir yaran bulunmadığını düşünüyoruz. Daha ziyade, gerektiği yerde, bu fiillerin, diğer maddelerde ongörülen fiillerle farklılık veya benzerlikleri üzerinde duracağız. Başka bir deyişle, suçlann diğer unsurlan da goz onünde tutulduğunda fiillerin bir veya diğer maddedeki suçu oluşturma olasıluklan ele alınacaktur.

"Bakanlık tasansında 342. maddenin [525/a] tümü hakkındaki gerekçede (s. 392) şu açıklama yapılmaktadır: "Birinci ve ikinci frkralarda yer alan suçlann teşekkülü için failin bir zarar elđe etmesi veya başkası için fiilen bir zarann meydana gelmiş bulunması şart yoktur, fiile teşebbüs etmiş olması suçun oluşmaşı için yeterlidir". Bu gerekçeden hareketle, burada bir "zarar suça" düşünülmediği ifade edilmiştir. tlk tasandan farklı olarak, bu bölüme giren suçlara teşebbüs haliyle tamamlanmış suçun cezasının verileceł̧i hükmü kanunda yer almamușur 60 .

Dolayısıyla, programlar, verileri veya diğer hertangi bir unsuru hukuka aykun olarak ele geçirmek maddî suç niteliğindédir. Öngörülen ceza yaptırımı suçun tamamlanmıs şekli içindir.

"525/a-1 fukrası bilgilerin gayrimeşru olarak ele geçirilmesị fiilini ongörmektedir. Ikinci fikra ise yazılımın (software) gayrimeşru kullammını cezalandırmaktadur. Belirtmek gerekir ki tipik filler, olması gerektiği gibi tanımlanmamışur. tkinci fıkrada yazılı "başkasına zarar vermek üzere kullanma" unsuru bu tipik fiil için uygun bir ifade gibi górünmemektedir. Unsur, hukuka aykın olarak "kendine ya da üçüncü kişilere çıkar sağlamak" olmalıydı. Iki fikrada da fail bilgisayan kullanarak kendine ya da üçüncü kişilere madđr̂ değer ifade eden bir çıkar sağlamaktadır"61.

\subsection{Ele geçirme suçu $(525 / a-1)$}

TCK'nun 525/a-1 fikrası "Bilgileri otomatik olarak işleme tabi tutmuş bir sistemden, programlan, verileri veya diger herhangi bir unsuru hukuka aykun olarak ele geçirme"yi suç saymakta ve hem özgürlüğ̈ü bağlayıcı ceza hem para cezası ile cezalandınimaktadir.

Bu fikrada, fiil, şeklî bir suç olarak düzenlenmiştir. Yapılan bir hareketle, program, veri veya diğer bir unsurun ele geçirilmesi halinde suç tamamlanmaktadır. Fiilin icrasına başlanmıs olup da bu hareketlerin failin elinde olmayan nedenlerle tamamlanamaması halinde eksik teşebbüs hükümlerine göre cezalandırma sőz konusu olacaktar.

60 Erem, a.g.y., s. 442.

61 Aydın O. D., a.g.y., s. 80. 


\subsection{Tasarruf suçu $(525 / \mathrm{a}-2)$}

Bu maddenin ikinci fikrasında yer alan hüküm ise, aynı nitelikteki bir programı, verileri veya dił̧er herhangi bir unsuru baskasına zarar vermek üzere kullanan, nakleden veya çợaltan kimseye de birinci fıkradaki fiil için öngörülen cezasın verileceł̧ini ifade etmektedir.

Bu fikrada ơngơrulen halde de kullanma, nakletme ve çogaltma hareketlerinin tamamlanması halinde suç tamamlanmış olacaktır. Sựun tamamlanması için Kanun ayrıca zarar meydana gelmiş olmasını gerekli görmediģi için tipik fiil aynca bir sonuç içermemektedir. Bu amaçlara yơnelik icra hareketlerinin failin elinde olmayan nedenlerle tamamlanamaması halinde eksik teşebbüs hükümlerine giore ceza verilecektir.

Bu fikrada ơngơülen ve ozel kastı ifade eden zarar amacının gerçekleşmesi halinde cezalandırma bakımından bir deģişiklik olmayacaktır. 'Zira Kanun koyucu bu amacın gerçekleşmesini bir ağırlatıcı neden olarak kabul etmemiştir.

Aynca 525/b-2 fikrası hükmü, yarar sağlama amacının gerçekleşmesi haliyle ilgili ayn bir suç ơngormektedir ve 525/a-2 fikrasında ơngorrülen fiildeki zarar verme amacının gerçekleşmesi halinde uygulanamaz.

\section{TCK 525/b Maddesindeki suçlar}

Bu maddenin iki fıkrasında ongörülen fiilleri mahiyetleri itibariyle değerlendirdiğimiz zaman, bunların her üç kategoriyi ("Bilişim araçlanna karşı suçlar", "Bilişim sistemleri aracılığı ile işlenen suçlar" ve "Bilişim sistemlerine karşı suçlar") ilgilendiren fiiller nitelił̆inde olduğunu görmekteyiz.

Aynı fukrada yer alan, "sistemi, verileri veya diğer herhangi bir unsuru değiştiren, silen veya sistemin işlemesine engel olan veya yarılış biçimde işlemesini sağlayan" deyimleriyle ifade edilen fiiller ise esas itibariyle bilgisayarnn elektro-manyetik ortamına karşı fiiller nitelił̧indedir. Dolayısıyla bu fiiller "Bilişim sistemlerine karşı suçlar" diye isimlendirilen kategoride degerlendirilmelidir.

525/b-2 fikrasında yer alan "yarar saglamak" fiili ise, bilgisayar ortamının suçun işlenmesinde araç olarak kullanılmasını ifade ettiği için, "Bilişim sistemleri aracılığıyla işlenen suçlar" kategorisinde düşünülmelidir.

\subsection{Bilgisayar sistemine ve ortamına karşı suç (525/b-1)}

Yukanda belirtmeye çalışığımız üzere, birinci fıkra hükmü incelendiğinde, burada mevcut "sistem, veri veya diger unsurun tahribi" kavramı, Kanun Koyucunun gerçek amacını aşan bir şekilde, bilgisayarın sadece elektro-manyetik ortamına yönelen fiilleri değil, fiziksel kısımları da ilgilendiren fiileri kapsayacak bir yoruma elverişli górünmektedir.

525/b-1 fıkrąsında ơngörülen "tahrip" fiili sistèmin donanım kısmını da ilgilendirebileceğinden "Bilişim araçlarına karşı suçlar" kategorisinden bir fiilin de bu kapsama sokuldựu izlenimi edinilmektedir. Ancak, yukanda 7.1.4. başlığı alunda "dił̌er herhangi bir unsur" kavramı ile ilgili açıklamalarda belirtildiği üzere, kanımızca, birinci 
fukrada sistemin fiziksel kısmına yőnelik fiillerin de cezalandırma kapsamına girmesi düşünülmemiş, sadece bilgisayar ortamına ilişkin fiiller cezalandırılmak istenmiştir. Kullanılan terim ve deyimlerin, bilgisayar dili anlamlannda degerlendirildiginde fiziksel kısımlara ilişkin fiilleri de kapsayacak şekilde anlaşılabilmesi, Kanun Koyucunun bilgisayar ortamını koruma yơnündeki gerçek amacını unuuturmamalıdır.

Bu düzenleme çerçevesinde, orneģin failin bir kimseye ait bilgisayarn herhangi bir ünitesini kurması, parçalaması halinde ceza bu maddeye göre değil herhangi bir başka taşınmaz mala yönelik yıkma, bozma, zarar verme fiilinde uygulanacak olan nâsı ızrarla ilgili 516. madde hükmü uygulanacakur.

\subsection{Bllgisayar ortamına müdahale filleri}

"Başkasına zarar vermek veya kendisine veya başkasına yarar sał̧lamak maksadıyla, bilgileri otomatik işleme tabi tutmuş bir sistemi veya verileri veya diğer herhangi bir unsuru kısmen veya tamamen tahrip" etmek silmek veya sistemin işlemesine engel olmak veya yanlış biçimde işlemesini sağlamak $525 / \mathrm{b}-1$ fukrasında suç sayilmaktadır.

"Tahrip" filleri de fiziksel kusımlara degil bilgisayarn elektro-manyetik ortamma yöneldiği olçüde bu kapsama girecektir. Ömeğin bin monitơrün tahribi sistemin fiziksel bir parçasının tahribi olarak Ceza Kanununun 516. maddesi hükmünde ongörtilen suçu oluşururken, içinde bulunan verileri ortadan kaldırmak için bir "sabit disk"i (hard disc) tahrip etmek fiili 525/b-1 hükmüne göre bilgisayar ortamma müdahale teşkil edecelcir.

Aynı şekilde, sistemin elektro-manyetik ortamı, veriler ve yine bu mahiyetteki herhangi bir unsura yơnelik "deģiştirme", "silme", "işlemeye engel olma", "yanlıs biçimde işlemeyi sağlama" fillerinin iş̧lenmesi halinde bu suçun maddí unsuru oluşacakur. Gơrüldügü gibi, bu fiiller bakımından da şeklî suç durumu sőz konusudur. Kanunda sayılan seçimlik hareketlerden herhangi birinin tamamlanması ile suç tamamlanmış olacakur. Bu suç bakımından da, tam teşebbüs mümkün olmayacak; ancak icra hareketlerinin failin elinde olmayan nedenlerle tamamlanamaması halinde eksik teşebbüs hükümlerine göre ceza verilebilecektir.

Genel kastın yanında, "başkasına zarar vermek" veya "kendisine veya başkasına yarar sağlamak maksadı" şeklindeki ơzel kasıt, manevî unsurun varlıł̆ı bakımından şartur.

\section{3 Yarar sağlama suçu $(525 /$ b-2)}

"Bilgileri otomatik işleme tabi tutmuş bir sistemi kullanarak kendisi veya başkası lehine hukuka aykırı yarar saglama" fiili 525/b-2 fıkrasında ongörülen suçu oluşturmaktadır

Burada öngörülen suç, bilgisayarların ve genellikle bilişim sistemlerinin kullanılması suretiyle en çok işlenen yarar sağlamaya yőnelik fiileri kapsamaktadır.

Daha önce örnegi verilen Ingiltere'deki $\mathbf{R} \mathbf{v}$ Thompson davasında olduơ̆u gibi, bilgisayara verilen bir komut veya yerleştirilen bir program ile maddí bir çıkar saglanması bu kapsama girecektir. 
Aynca "yarar sağlamak" geniş bir kavram oldư̆u için, madđ̛, manevî, kültürel her türlü yarar bu kapsama girebilecektir. Örneğin, belli bir hukuk programından abone olmak suretiyle yararlanmak gerekirken, şifre çözülerek yararlanılması bu kapsamda degerlendirilecektir.

"Yarar sağlamak" kavramının bobylesine geniş anlamının bulunması nedeniyle, ozellikle Ceza Kanununda mevcut, hırsızlık, dolandırıcilık, güveni kottüye kullanma gibi "maddi çıkar" sağlama fiillerinin bilişim araçlarının kullanılması suretiyle işlenmesi halinde durumun ne olacał̆ı, nasıl bir değerlendirme yapılacağı üzerinde durmak gerekir. Zira, bilgisayar aracılığıyla yapılan haksız bir işlem sonucu bir kimse kendisine veya başkasına maddî bir çıkar sağlamış ise bunun bir "yarar sağlama" sayılacağında kuşku yoktur. Boyle bir fiil mahiyetine göre yukanda sayılan suçlardan biri olarak kendisini gosterebilir. Bu durumda aynı fiile 525/b-2 fikrası hükmünün de uygulanabilir olması sonucu, bu "górünüşste kurallar içtimaı" (concorso apparente di norme) durumunun değerlendirilerek, fiile hangi kuralın uygulanacağının saptanması gerekir.

Kanunun bilişim suçlan ile ilgili maddelerinde, "fiil ayn bir suç oluşturmadığg takdirde" veya "fiil daha ağır bir cezayı müstelzim olmadığı takdirde" gibi ibarelerle başka kuralların uygulanabilirliģini kabul eden bir düzenleme yoktur. Bu nedenle bir fiile birden çok kural uygulanabilir olduğu zaman bunların birinin veya diğerinin uygulanması gerektigini belinten bir sistem burada ơngörülmemiştir.

Bilindiği üzere, görünüşte kurallar içtimaı, bir fiil birden fazla kuralın uygulama alanı içine girdił̧i zaman sozz konusu olur. Yukarıda saydığımız türden bir fiil bilgisayar sistemi kullanılmak suretiyle işlendiğinde aynı fiile birden çok kuralın uygulanması durumu ortaya çıkmaktadır.

Bu halde hangi kuralın fiile uygulanması gerektiği açısından kurallar arasındaki ठzellik-genellik ilişkisine bakmak gerekecektir. Aynı fiile uygulanabilir birden fazla kural söz konusu olduğunda bunlar arasındaki ozzellik-genellik ilişkisinin saptanması her zaman kolay deģildir. Bu değerlendirmeyi yaparken başvurulması gereken olçüt, bir kuralın ongördügü fiilin, şayet o kural mevcut olmasıydı diğer kuralın kapsamı içerisine girip girmeyeceğidir. Sayet bir kural olmasaydı fiil diğer kuralın kapsamına gerecek idiyse birinci kural ikinciye göre özel nileliktedir ve uygulanması gerckir.

Değerlendirme konusu "bilişim sistemini kullanarak hukuka aykırn yarar sağlama fiili", şayet bu yarar saglamanın bilişim sistemi aracılığıyla olması halini ayrıca düzenleyen bu hüküm olmasıydı, fiilin mahiyetine göre yukarıda sayılan suçları ongören kurallardan birine göre cezalandırılabilicekti. Çünkü o maddelerde de başkasının "taşınabilir malını ... faydalanmak için bulundugu yerden alan" kimse (m. 491), "hile ve desiseler yaparak hataya düşürüp ... menfaat sağlayan kişi" (m. 503), "kendisine tevdi ... olunan bir şeyi ... sarf veya istihlâk" eden kimse (m. 508) hakkında ceza yapuırımı óngörülmektedir.

Cezalandırmanın ozzei hüküm olan 525/b-1 fikrası hükmüne göre yapılması, diğer hükümlerde öngörülen yaptınmlarla farklılıklar bulunması nedeniyle bazı tutarsız sonuçların ortaya çıkmasına yol açabilecektir. Çünkü kanımızca, yukanıda sayılan maddeler kapsamına girebilecek fiillerin bilgisayar aracalığıyla işlenmesi halinde tek bir 
yaptırım olçütüne gơre cezalandınlacak olması, o maddelerle ilgili düzenlemelerdeki ozzelliklerin gőz önünde bulundurulmasını engelleyecektir.

Benzeri değerlendirmeleri, 525/b-1 fikrası hükmüne göre genel nitelikte goriünen diğer maddeler bakımından da yapmak mümkündür. Ancak önemli olan, burada çeşitli ve orantılılık açısından açıklaması zor durumları sergilemek değil, genel olarak Ceza Kanununa bir yeni "bab" eklenirken sistem bakımından ortaya çıkan sakat duruma işaret etmektir.

525/b-2 fikrası hükmünün uygulanabilirliģi bakımından, Ceza Kanununun 202. maddesinde óngorrülen zimmet suçuyla ilgili olarak da değerlendirme yapmak gerekir. "Yarar sağlama" unsuru zimmet suçunda da bulunmakla beraber, bu suçu ancak memur sıfatına sahip bir kimsenin işleyebilmesi dolayısıyla, fiilin bir bilişim sistemi aracılığılla işlenmesi halinde Ceza Kanununun 525/b-2. fıkrası hükmü değil, ozel hüküm olan 202. madde hükmü uygulanacaktur.

Bilişim suçları ile ilgili hükümlerle beraber Ceza Kanununa eklenen maddeler arasinda olan 521/b maddesinde óngörülen otomatik aletlerden odeme yapmadan yararlanma suçunun 525/b-2 madesindeki suçtan farklılığını da değerlendirmek gerekir. Buradaki otomatik aletlerin "bilgileri otomatik olarak işleme tabi tutan" bir sistemleri olmadığı takdirde sorun yoktur. Ancak, standartlaşmış yiyecek, içecek veya başka tür malzeme dağıtımı ile ilgili bu makinelerin ufak çapta da olsa bilgi işlem içeren tipleri geliştirilmektedir. Boyle olunca ve bilgisayarla verilen hizmetlerde de genellikle bedeli karşılığı hizmet verildiği için iki hükümden hangisinin uygulanması gerektiği konusunda tereddüt ortaya çıkabilir. Böyle bir durumda, şayet 525/c maddesinin unsurlan varsa, $521 / \mathrm{b}$ maddesindeki açıklık dolayısıyla fiil daha ağır suçu oluşturduğu için 525/c maddesine göre ceza verilmesi gerekecektir.

\section{TCK 525/c Maddesindeki suf̧}

\section{1. Sahte belge düzenlemek için veri yerleştirmek fiili}

$525 / \mathrm{c}$ maddesinde, hukuk alanında delil olarak kullanılmak maksadiyla sahte bir belgeyi oluşturmak için bilgileri otomatik olarak işleme tabi tutmuş bir sisteme, verileri veya diğer unsurlan yerleştiren veya var olan verileri, diğer unsurları tahrif eden ve tahrif edilmiş veriler bilerek kullanan kişinin ilk iki halde bir yıldan ü̧̧ yıla kadar ve sonurıcu halde alu aydan iki yıla kadar hapis cezası ile cezalandırılması óngörülmektedir.

Bu maddede öngörülen fiiller yakından incelendiğinde, teşebbüsün tamamlanmış suç gibi cezalandınıldığını görmekteyiz. Madde hükmüne göre, delil olarak kullanmak amaciyla sahte bir belge oluşturmak için sisteme verileri yerleş̧tirmek suç teşkil etmektedir. Anlaşılacağı üzere, ortada henüz sahte bir belge yoktur. Ancak fail, böyle bir belge düzenlemek üzere bilgisayar sistemine veri yerleştirmektedir. Ömeğin bir fakültenin bilgisayar sistemine gerilerek bir ơgrencinin notunu deģiştirilmesi bu suçu oluşturacaktır.

Ceza Kanununun 345. maddesinde ozel evrakta sahtekârlık halinde zarara yol açabilecek böyle bir evrakı sadece düzenlemekle kalmayıp ayrıca kullanan kişiye uygulanan ceza (bir yıldan üç yıla kadar hapis cezası), 525/c maddesinde delil olarak kullanılmak amacıyla sahte bir belge oluşturmak için sisteme veri yerleştiren kişiye verilmektcdir. 
Kanunun ơngơrdügü ozel kasun, yani "delil olarak kullanmak amacının bu fiili Kanun Koyucu gözünde daha ağır bir fiil haline getirdiģi anlaşılmaktadır. Ancak tanımlanan fiilin uygulamada nasıl bir fiil şeklinde ortaya çıkabileceł̆ini değerlendimek istedigimizde güçliukle karşılaşmaktayız.

\section{2. Sahte belge düzenlemek için veriler tahrif fiili}

Maddede tanmlanan bir diger fiil, yine delil olarak kullanma amacıyla, sahte bir belge oluşturmak için, sistemde var olan verileri (veya diğer unsurları) tahrif etmek suç sayılmıştur. Burada da diłgerinden farklı bir hukukî durum olduğu sóylenemez. Zira yine bir sahte belge düzenlenmesi için mevcut verilerde tahrifat yapılması söz konusudur. Henüz ortada sahte bir belge yoktur. Burada tahrif konusu olabilecek "diger unsurlar" in neler olabileceł̧i de açık deģildir. Bundan önceki halle ilgili olarak sőylenenler burada da geçerlidir.

\section{3. Tahrif edilmiş verileri kullanma fiili}

Bu madde hükmünde, delil olarak kullanma amaciyla sahte bir belge düzenlemek için tahrif edilmiş verinin kưllanılması da suç sayılmaktadır. Ancak bu kullanmanın da "hukuk alanıdo delil olarak kullanılmak maksadıyla sahte bir belgeyi oluşturmak için" mi olacağı hususunda kanunda netlik yoktur. Yazılıs tarzı herhangi bir şekilde kullanmayı da suç saymaya imkân verecek şekildedir. ancak maddenin genel mantığı içerisinde bu kavramı bőylesine geniş anlamamak gerektił̌ini düşünüyoruz. Başka bir deyişle, burada öngợülen tahrif edilmiş verilerin kullanılmasının da yine delil olarak kullanmak amacıyla sahta belge düzenlemeye yönelik olması gerekir.

Bu kullanma sonucunda maddede óngörülen sahte belgenin oluşması halinde, hukukî tahlilin ne olacağı ve cezalandırmanın hangi maddeye göre olması gerektił̧i hususu da tartışmaya yol açabilecektir.

Maddenin genel anlayışı ve tanımlan sahte belge düzenlenmesini cezalandırmaya yönelik görünmemektedir. Özellikle, maddede, veri yerleştirme ve verileri tahrif fiillerine bakınca, Kanunun bu maddesindeki hükmün, yukarıda belirtildigi gibi, bilgisayar ortamında sahte evrak düzenlenmesine teşebbüs fiillerini tamamlanmış suç gibi cezalandırmaktadır. Bu şekliyle 525/c maddesi hükmü, 339. ve sonraki maddeler hükümlerine göre özel hüküm niteliginde görülemez. Zira bu hükümde öngörülen filler, bu hüküm olmasaydı 339. ve sonraki maddeler hükümlerine göre cezalandırılamayacaktı. Dolayısıyla, bilgisayar sistemi aracılığıla sahte belge düzenlendiği takdirde, evrakın resmi veya ozel olmasına gớre, Kanunun 79 . maddesi hükmü uyarınca daha ağır cezayı gerektiren madde hükmüne göre ceza verilecektir.

$525 / \mathrm{c}$ maddesinde belirtilen tahrif edilmiş verileri kullanma hali aynca belirtilmiş ve bu fiile önceliklere göre daha az ceza öngörülmüştür. Eğer tahrif edilmiş bilgileri "kullanma"yı sahte belgeyi oluşturma halini de kapsayacak şekilde anlayacak olursak, bilgisayarda sahte belge oluşıurma bakımından özel bir hüküm düzenlenmiş olduğu ve bu halde bu hükmün uygulanıp burada öngörülen cezanın uygulanması gerektiği sonucuna varilabilir. 
Ancak, kullanma kavramının sahte belge düzenlemeyi de kapsamadığını düşünüyonuz. Böyle olsaydı bir kez Kanun Koyucunun buhu açıķa sobylemesi gerekirdi. Aynca, birinci yorum kabul edildiği takdirde ortaya çıkacak sonuç Kanunun şimdiye kadar gördügümüz bu maddeyle ilgili mantuğına da ters düşmektedir. Gerçekten, ozel hüküm olarak bu madde uygulanıp tahrif edilmiş veriyi kullananlar için azalularak ongorrülmüş cezanın uygulanacağı kabul edilecek olursa, Kanunda bilgisayarla sahte evrak düzenlemeye teşebbüsü dahi tamamlanmış suç gibi cezalandıran mantığa ters düşülmüş̧ olacakur.

\section{Manevi unsur}

Hukukumuzdaki düzenlemeye gơre, cürüm niteliğindeki bilişim suçlannda manevî unsur ancak kasun varhı̆̆ halinde oluşacakur. Kanun, óngörülen fiillerin taksirli şeklinin cezalandurilmasına gerek görmemiştir.

Aynca, 525/a-1 fikrasındaki fiil dışında kalan fillèrde, sadece genel kasun bulunması yetmemekte; "başkasına zarar vermek" (525/a-2), "baskasına zarar vermek veya kendisine veya başkasına yarar saglamak" (525/b-1), "kendisi veya baskası lehine hukuka aykın yarar sağlamak" (525/b-2) ve "hukuk alanında delil olarak kullanılmak" (525/c) maksadı şeklinde ozel kasıt unsurlanının varlığı fiillerin suç sayılması için gerekli görülmektedir.

Uygulamada manevî unsurun değerlendirilmesi bakımından bazı ilginç durumlar ortaya çıkabilecektir. Ömeğin, bir bilgisayar sistemine izinsiz girilmesi fiili Ceza Kanununda suç olarak öngörülmemiştir. Izinsiz giriş yapan fail istemeden programlan zarara uğratmış ise, Ceza Kanununda öngörülen suçların taksirli şekilleri cezalandınılmış olmadıgından, bu fiil de suç teşkil etmeyecektir.

Hattâ, kasıtlı olarak işlenen orneģin "programı değiştirme" fiilinde mutlaka "başkasına zarar vermek veya kendisine veya başkasına yarar sałlamak": amacının da (525/b-1) bulunup bulunmayacağı taruşılabilecektir. Program tahribi, silinmesi veya değiştirilmesi gibi bir sonuç doğuran hareketin zarar vermesi veya yarar sağlaması kaçınılmaz olduğuna göre, ayrıca bir de özel kasun aranmasının gereksiz oldư̆u ileri sürülebilir.

Bunun gibi, 525/a-2 fikrasında bir programı, verileri veya diğer herhangi bir . unsuru "başkasına zarar vermek üzere" kullanmak, nakletmek ve çoğaltmakdan sóz edilmesi de isabetli görünmemektedir. Zira, böyle fiiller, başkasına zarạr vermekten ziyade kendisine ya da başkasına yarar sağlamak amacıyla işlenirler 62 .

Bu durumda, genel olarak manevî unsur değerlendirmesinin ózenle yapıldığını söylemek zordur.

\section{Ceza yaptırımı}

$525 / \mathrm{b}$ maddesinin iki fikrası arasında açık bir tutarsızlık bulundugu kanaatindeyiz. Zira, birinci fıkrada ơmeğin "yarar sağlamak amacıyla sistemin yanlı̧ biçimde işlemesini

62 Aydin O. D., a.g.y., s. 80 
sağlamak" iki yıldan alı yıla kadar hapis ve beşmilyon liradan ellimilyon liraya kadar ałır para cezasını gerektirirken, ikinci fukrada "bir sistemi kullanarak yarar sałlamak" bir yıldan bes yıla kadar hapis ve ikimilyon liradan yirmimilyon liraya kadar ağu para cezasını gerektirmektedir. Ikinci fikradaki fiil de birinci fıkradaki fiil gibi bilgisayar ortamı kullanılması suretiyle işlenmektedir. Birinci fikrada sadece amacın yarar sał̆lamak olması yeterli iken ikinci fıkrada yararın elde edilmiş olması da gerekmektedir. Kısaca sరbylemek gerekirse, birinci fukrada yarar sağlamaya teşebbüs hali suçun tamamlanmasına yetmektedir. Bu durumda aynca yaranı sał̆lanmıs olması cezayı ał̆ırlaştuncı bir durum olmak gerekirken, ikinci fıkrada daha az ceza ongörülmesinin mantıklı bir açıklamasını bulmak zordur.

Kanunun 525/d maddesi hükmü, çok net bir şekilde olmasa da, 525/a ve 525/b maddelerinde yazılı suçlan meslek icrası sırasında veya icrası dolayısıyla işleyen kişilerin, suçun işlendiği kamu hizmetinden veya meslek veya sanat veya ticaretten belirli süre yasaklanmasını hükme bağlamaktadır. Bu yasaklama ek cezasının, 525/c maddesinde yazılı "delil tahrifi" fịlinin faillerine niçin uygulanmadığının mantıklı bir açıklamasinı biz bulamamaktayız ${ }^{63}$.

\section{IV-SONUÇ}

Nisbeten yakın bir zarnanda kullanılmaya başlayan ve Ülkemizde de son yıllarda kullanımı yaygınlaşan bilgisayarların ve bilgisayar esasına dayalı diğer araçların, çok çeşitli çalışma alanlannda sagladıklan büyük imkânlar nedeniyle tüm dünyada yeni bir çă̆ başlatukları kanısındayız. Bu araçlar sadece ợretim, oğrenim, çalışma alanlannda değil insan hayatının her yönii bakımından gittikçe artan bir önem kazanmaktadır.

Bu durumda, sőz konusu araçları, sistem, program ve verilerini kullanmanın ortaya çıkardıłı ve sadece Ceza Hukuku ile sınırlı olmayan çok çeşitli hukukî sorunlan ciddî araşurmalarla değerlendirildikten sonra tuarlı ve geçerli bir yasal düzenlemeye kavuşurmak şartır.

Bu inceleme içerisinde, Ülkemiz ve hukukçulanmız için nisbeten yeni ve oldukça değişik teknik ozzellikleri olan bu konuyu değerlendirmeye çalıştık. Metin içerisinde, bu konuyla ilgili hukuk kurallarının saptanmasında, hukukçularla bilgisayar uzmanlarının ortak çalışma yapmalan gereł̧ini dile getirtił̆imiz halde, itiraf etmeliyiz ki bu çalışmayı, bilgisayar uzmanlarının yayınlarından yararlanmakla beraber, sadece bir hukukçu olarak yapmak zorunda kaldık. Bunun doğal sonucu olarak, çalışmamızda kaçınılmaz şekilde birtakum hatalar ve eksiklikler bulunacakur.

Ancak, bunlara rağmen, konuya ilişkin değerlendirmelerin, ileride yapılacak daha kapsamlı ve daha aynntılı incelemeler için düşündürücü unsurlar taşımakta olmasını diliyoruz.

Buraya kadar yapmıs oldugumuz açıklamalan sonuç başlığı altında tekrarlamak niyetinde olmamakla beraber, ozelliği olan bazı konulara kısaca değinmeyi yararlı gơrüyoruz.

63 Aydin, O.D., a.g.y., s. 80. 
Bilişim alanında ortaya çikan genel hukuki düzenleme ihtiyacına karşın, sadece Ceza Hukuku alanında sınurh bir düzenleme ile yetinilmiş bulunmaktadır. Simdiye kadar bazı girişimlerde bulunulmuş olmakla beraber, Ozel Hukuk alanında hukukî düzenleme yapılmamıs bulunmaktadır. Mevzuatımızda FSEK'nun ongobrdügü sistemin "eser" sayılmak suretiyle bilgisayar programlanna uygulanabilirliği tarışmalıdır.

Bilişim alanında ortaya çıkan hukukî koruma ihtiyacının genel olarak ele alınıp, bu çerçevede cezaî korumanın ne olması gerektiği saptanmak gerekirken, boyle yapılmamıs ve bir yabancı tasandan yararlanılarak Ceza Kanununa "Bilişim Alanında Suçlar" başlkklı dơrt maddelik bir "Bab" eklenmiştir.

Bu maddelerle getirilen hükümlerin yeterince isabetli olduklan ve sistemle tutarlı hale getirildikleri sóylenemez. Bu bakımdan, Ceza Kanununa yapılan ekleme, bilgisayar çă̌ııın ortaya çıkardı̆̆ı hukukî düzenleme ihtiyacının hissedildiğini göstermes̀i bakımından olumlu sayılabilmesine karşın, yetersiz ve sınırı bir çaba olarak kalmışur.

Bu konudaki hukukî düzenlemelerin, elbette yabancı ülkelerdeki ơmeklerden yararlanılarak, ancak Ülkemiz ortamının özellikleri de göz onünde tutularak yeniden ve daha genel çerçevede ele alınması, ciddł çalışmalarla değerlendirilmesi ve tüm hukuk sistemimiz içinde tutarlı hükümler bụtünü olarak oluşturulması zorunludur.

Bunu yapabilmek için, hukukçuların bilişim ve bilgisayar alanının uzmanlanyla ortak çalışmaları gerektił̧ini, tekrar pahasına da olsa, vurgulamak istiyonuz. Bilgisayar kullanan hukukçu olmak bazı kavramlara aşinalığa yol açabilirse de, bilgisayar sistem, program ve verilerin kendine ozgü yapı ve sorunlannın anlaşılması, bu alanın uzmanlarının katkısı olmadıkça mümkün değildir. Elbette aynı zamanda bilgisayar konularının uzmanı olan hukukçular bulunabilir ve kendilerinin hukukỉ düzenlemeler için deģerli onerileri olabilis. Fakat, hem konunun ozzelliği hem de yasal düzenlemelerin, gerçek anlamında gerekçeleriyle birlikte, ciddî ortak çalışmalarla oluşturulabileceği gerçegi karşısında, bireysel çabalar oancak sınırı katkı sağlayabilirler.

Bu bakımdan, bir yandan hukukçular ve bilgisayar uzmanlan konuya ilişkin kendi değerlendirmelerini yaparken, Adalet Bakanlığı'nda oluş̧urulacak bir komisyonun konu üzerinde sürekli çalışmak suretiyle, dünyada ve Türkiye'de mevcut doktrin, içtihat ve yasal düzenlemeleri de göz önünde tutarak, konuyu hukukî bakımdan her yönüyle düzenlemeye yơnelik çalışma yapmahıdır. Ancak o zaman, bugünün ve ozellikle geleceğin konusu olan bu alanda geçerli ve autarlı hukuk kurallan oluşturmak mümkün olacakur. 